This is the Author's Accepted Manuscript version (final draft post-refereeing as accepted for publication by the journal). The definitive, peer-reviewed and edited version of this article is published as: van Ham M., Uesugi M., Tammaru T., Manley D. \& Janssen H. (forthcoming) Changing occupational structures and residential segregation in New York, London and Tokyo. Nature Human Behaviour. DOI: https://doi.org/10.1038/s41562-0200927-5; and public Sharedlt link: https://rdcu.be/b6jl7

\title{
Changing occupational structures and residential segregation in New York, London and Tokyo
}

Maarten van Ham ${ }^{1,2^{*}}$, Masaya Uesugi ${ }^{3}$, Tiit Tammaru ${ }^{1,4}$, David Manley ${ }^{1,5}$ \& Heleen Janssen ${ }^{1}$

${ }^{1}$ Department of Urbanism, Faculty of Architecture and the Built Environment, Delft University of Technology, Delft, The Netherlands

${ }^{2}$ School of Geography \& Sustainable Development, University of St Andrews, St Andrews, UK

${ }^{3}$ Faculty of Socio-Environmental Studies, Fukuoka Institute of Technology, Fukuoka, Japan

${ }^{4}$ Department of Geography, Institute of Ecology and Earth Sciences, Faculty of Science and Technology, University of Tartu, Tartu, Estonia

${ }^{5}$ School of Geographical Sciences, University of Bristol, Bristol, UK

* Corresponding author: Maarten van Ham (m.vanham@tudelft.nl; ORCID https://orcid.org/00000002-2106-0702).

\begin{abstract}
Based on data from the 1980s, Sassen's seminal book 'The Global City' asked how changes in the occupational structure affect socio-economic residential segregation in global cities. This paper reframes and answers this question for recent decades, using data for New York, London and Tokyo. Our analysis shows an increase in the share of high-income occupations, accompanied by a drop in low-income occupations in all three cities, providing strong evidence for a consistent trend of professionalization of the workforce. Segregation was highest in New York, and lowest in Tokyo. In New York and London, individuals in high-income occupations are concentrating in the centre, while low-income occupations are pushed to urban peripheries. Professionalization of the workforce is accompanied by reduced levels of segregation by income, and two ongoing
\end{abstract}


megatrends in urban change: gentrification of inner-city neighbourhoods and suburbanization of poverty, with bigger changes in the social geography than in levels of segregation.

\section{Introduction}

The Global City thesis (or social polarization thesis), developed by Sassen ${ }^{1,2}$, linked globalizationinduced transformations of urban economic structures with increasing social polarization by occupation and income. Taking London, New York and Tokyo as exemplars, Sassen argued that global economic restructuring is leading to the decline of manufacturing and the growth of producer services and finance. This results in increasing numbers of highly skilled workers earning the highest incomes, such as professionals and managers, and a simultaneous expansion of the group of lowskilled workers earning the lowest incomes. Since the publication of Sassen's book 'The Global City' ${ }^{1}$, there has been a prolonged debate about the social polarization thesis. According to Hamnett ${ }^{3}$, the concept and definition of social polarization is ambiguous, omitting other occupational trends. For example, empirical work in London provides supporting evidence for processes of professionalization ${ }^{4}$ and socio-economic upgrading ${ }^{5}$, although more recent evidence indicates that there are also other forms of occupational changes since 2000.6,7 Hill and Kim ${ }^{8}$ further argued that there are important differences between liberal capitalist states and developmental states. Tokyo is characterized by late industrialization and this potentially leads to different trajectories of occupational change compared to London and New York. The variety of national experiences and outcomes for global cities questions the validity of the Global City thesis on occupational change over space and time.

The polarization thesis ${ }^{1,2}$ pays particular attention to urban spaces where the changes in industrial, occupational and earnings structures manifest themselves. In her book Sassen ${ }^{2}$ uses the idea of spatial polarization, and asks the question "how the greater income polarization in the leading industries (...) is constructed socially; that is to say, is it merely a change in the income distribution, or are there new social forms associated with an increase of high-income and of low-income workers? What is the social geography emerging from this transformation?" Our study focusses on the latter part of this question; on the changes in residential segregation between income-based occupational groups in global cities. A recent study of socio-economic segregation in European capital cities observed increasing levels of residential segregation between the top and bottom occupational status groups since the $2000 \mathrm{~s}^{9}$, with the rich and poor increasingly living separated lives. The study suggested that increasing levels of socio-economic segregation are the result of interactions between welfare provision and housing systems, the lasting imprint of historical developments and other forms of segregation, as well as increasing inequality and changing 
occupational structures under the influence of globalization. Additionally, segregation patterns also depend on national and local contexts ${ }^{10-12}$. Thus, even if globalization does result in changes in the occupational structure, the geographical manifestation of that change is unlikely to be uniform across cities and nation states. Based on a literature review on the forces shaping socio-economic segregation, as well as on the way in which they play out in different local contexts (see the supplementary discussion), we expect that the growth in residential segregation between incomebased occupational groups since the 1980s will be the greatest in New York and the smallest in Tokyo, leaving London in-between.

This paper studies changes in residential segregation between 1980 and 2010/11 in Sassen's original three global cities ${ }^{1,2}$ : New York, London and Tokyo. The following research questions are addressed: 1) To what extent has the occupational structure in the three cities changed since the 1980s?; 2) To what extent have levels of residential segregation changed between high- and low-income occupational groups?; 3) How has the geography of the residential distribution of high- and lowincome occupations changed over time? The answers to these questions help to better understand the changes in the occupational structure (professionalization versus polarization) and how they link to changes in residential segregation between income-based occupational groups in global cities.

This study uses national census data for the period between 1980-2010/11 reporting on occupational status, aggregated into small areas, in all three cities. We classify occupations as highincome, middle-income and low-income, and study the changes in segregation indices and the associated geographies of segregation. Usually, occupation-based segregation studies ${ }^{9}$ ignore the income levels of different occupational groups. This is an important shortcoming since occupations can experience significant changes in income over time. Moreover, it is income and not occupation that buys choice in the housing market ${ }^{13}$, and high-income groups tend to define the evolution of patterns of residential segregation ${ }^{14,15}$. To overcome this problem, we used nationally representative survey data for each census year and for each city, containing information on occupations and income, to create income-based occupational groups that will be used also for characterizing changes in occupational structure in the next section.

\section{Results}

\section{Occupational structure change}

Figure 1 shows the changing occupational structure between 1980 and 2010/11 for New York, London and Tokyo using three income-based occupational categories (high, middle and low). A 
detailed direct comparison of the income-based occupational structures of the three cities is difficult as there are small differences in the data, and changes over time in classifications. We therefore focus on more general trends instead of detailed differences.

In New York, there is noticeable growth of the high-income occupational groups, and clear shrinkage of the middle-income occupational group since 1980. The share of individuals belonging to the bottom or low-income occupational group decreased slightly between 1980 and 2000. However, it is notable that there is a small increase in the proportion of the low-income occupational group between 2000 and 2010. So, while the high-income occupational group increased by almost 12 percentage points from 25.9 percent to 37.6 percent between 1980 and 2010, it was at the expense of the middle group, which fell from 50.6 percent to 40.1 percent. The low-income occupational group stayed stable at around 22-23 percent when comparing 1980 and 2010. The clear growth of the high-income occupational group, accompanied by a thinning out of the middle group, and a stable low-income group, provides support for occupational professionalization taking place in the occupational structure of New York between 1980 and 2010.

*** Figure 1 about here $* * *$

In London, there was a sharp increase in the share of individuals belonging to the high-income occupational group accompanied by a significant decrease of the proportion of the population in the low-income occupational group between 1981 and 2011. The sharp drop in the share of the lowincome group between 1991 and 2001 is partly an artefact of the broad categories of occupations that were available to us, but the general trend is clear. Interestingly, as with New York, there is also a small increase in the share of the low-income occupations between 2001 and 2011 in London. Although there was quite some variation in the size of the middle group, the share varied between 41 and 43 percent when comparing the years 1981 and 2011. The data suggests that in London a process of professionalization also took place during the $1980 \mathrm{~s}$ and the $1990 \mathrm{~s}^{3}$. In 1981 , the size of the low-income occupational group was twice that of the high-income occupational group, but during the 1990s this pattern started to change, and by 2011 the high-income occupational group was much larger than the low-income occupational group. Overall, the occupational structure of London is also characterized by professionalization between 1980 and 2010.

When comparing London with New York in 1981, it is clear that in London the high-income occupational group was much smaller, and the low-income occupational group much larger. However, by 2010/11 the occupational distribution of the three groups has become similar in both cities. A big difference between the two cities is that in New York the middle group became much smaller, while in London this group remained stable. Although the changes between 2000/1 and 
2010/11 are small, in both cities the share of the low-income occupational group increased somewhat. This might suggest marginal polarization between 2000 and 2010 at the expense of the middle group (which remains the largest). However, there is also the important caveat that small changes might be an artefact of the categories used and the changes in definitions over time rather than real change.

The changes in the occupational structure of Tokyo show a clear trend of professionalization between 1980 and 2010. The share of the high-income occupational group increased, and the share of the low-income occupational group fell, with the consequence that the middle-income group remained more or less stable over time. It is noticeable that the extent of change in the high-income occupational group is much smaller in Tokyo compared to the other cities. A consequence of this limited change is that the high-income occupational group in Tokyo in 2011 is much smaller compared with the other two cities: 23.8 percent. This share is comparable with the situation in New York and London in the 1980s. The low-income occupational group in Tokyo has decreased constantly between 1980 and 2010, from 36.1 percent to 28.9 percent, but even then, this group in Tokyo remains larger than in the other two cities.

Our first research question was to what extent has the occupational structure in the three cities changed since the 1980s? The three global cities show distinct patterns of income-based occupational structures and change over time, but they all share a strong and consistent growth of the high-income occupational group, and a stabilizing (New York), or shrinking (London and Tokyo) low-income occupational group. Our analyses show a consistent trend of professionalization of the occupational structure in all three cities as suggested by Hamnett $^{3}$, and we found no evidence for the social polarization thesis by Sassen ${ }^{1}$. Only between $2000 / 1$ and 2010/11 there is a small increase in the share of low-income occupations in New York and London, which could hint towards polarisation, but even so, in both cities the share of the low-income group was smaller in 2010/11 than in 1980/1. Crucially, in all three cities the middle-income group remained the largest.

Despite the commonalities, there are also differences between the cities. In New York, there is clear shrinkage of the share of the middle-income group since 1980, while the share of the low-income occupations has remained more or less stable. In London the middle-income group remained stable, while the share of the low-income group has dropped, which is similar to what can be seen for Tokyo. In New York and London the share of the high-income occupations has grown much faster than in Tokyo. In conclusion, our results show a clear trend of professionalization of the workforce in New York, London and Tokyo, in line with the professionalization thesis as proposed by Hamnett ${ }^{3}$. 


\section{Level of socio-economic residential segregation}

To answer the second research question we investigate changes in levels of residential segregation between occupational groups (using the same three income-based occupation categories as before) in each of the three cities and explore if these changes are related to changes in their occupational structures. Table 1 shows the Index of Dissimilarity (ID) and the Multi-group Dissimilarity Index (MDI) for all three cities between 1980 and 2010 for high-income and low-income occupational groups. For Tokyo there was no consistent small-scale geography available over the four censuses used, and therefore data is presented for two temporally overlapping spatial units (Cho districts and $500 \mathrm{~m}$ square grid cells).

Table 1 highlights that New York consistently has the highest levels of socio-economic residential segregation compared to the other two cities. For example, in 2010 New York had an ID value of 0.42 , and an MDI value of 0.27. The ID for New York dropped somewhat between 1980 and 2000, but then climbed again to the 1990 level. The MDI for New York first dropped, but then increased between 1990 and 2010. These results suggest a stable level of segregation between high-income and low-income occupational groups, but with increases in the last decades, especially when all three groups are taken into account.

*** Table 1 about here $* * *$

By contrast, in 2010, Tokyo is the least segregated city of the three, with an ID value of 0.23 , and an $\mathrm{MDI}$ value of 0.12 . Furthermore, both indices demonstrate a decrease in socio-economic residential segregation between 1980 and 2010, regardless of the geographical units used. This decrease in segregation is consistent and quite remarkable, especially given the suggestion from the literature that levels of segregation are increasing in global cities. The pattern of change in segregation in London is similar to that of New York, but more pronounced: In the 1980s the level of segregation dropped (as measured by ID) and then it increased again in the next decades. It is important to note that the ID value for London increased between 1990 and 2000, and this might have been caused by reclassifying "Administrative and secretarial occupations" from the low-income occupational group to the middle-income occupational group, and therefore the share of the low-income occupational group declined in this period.

Overall, the drop in segregation in all three cities coincided with strong and consistent professionalization of the labour force. This suggests a link between professionalization and reducing levels of segregation by income. Interestingly, for both New York and London, the share of low-income occupations increased slightly between 2000/1 and 2010/11 and this coincided with a slight increase in the level of segregation by income. It may be the case that increasing levels of 
polarization in the workforce are linked with increasing levels of segregation, but to be certain we need to see the 2020/1 round of Census data to confirm this hypothesis. Despite the potential links between changes in the occupational structure and levels of residential segregation, we have to point out that the levels of segregation in London (measured by MDI) have been much more stable than the occupational structure. In other words, substantial changes in the occupational structure do not necessarily translate into large changes in residential structures as measured by segregation indices, or at least not immediately as there might be time lags.

Our second research question asked to what extent levels of socio-economic segregation have changed between the top and bottom income-based occupational groups. We found considerable differences between the three cities, with New York being the most segregated city and Tokyo being the least segregated. In 2010, the value of the ID between high-income and low-income occupations was 0.42 in New York, 0.31 in London and 0.23 in Tokyo. We observed relatively little change in the levels of segregation in each city, despite profound changes that took place in the occupational structures. The ID for New York fell between 1980 and 2000, but then increased again in 2010 but the overall outcome for the study period was that residential segregation between occupational groups was slightly lower in New York at the end. Changes in the level of socio-economic segregation are similar in London to what we found for New York: in the 1980s the level of segregation dropped and then increased again in the following decades. Unlike New York, London was somewhat more segregated in 2010 compared to 1980. By contrast, the ID is not only lower in Tokyo compared to London and New York, but we can also observe a steady decline during the 1980-2010 study period.

\section{The social geography of changing occupational structures}

The city-wide single-number indices of segregation only part-tell the story of the changing social geographies in New York, London and Tokyo, and potentially mask important underlying changes. In theory, without any change in segregation levels, the underlying social geography of where different occupational groups live, can change completely. Figures 2 and 3 respectively show the spatial distribution of the high-income and low-income occupational groups. The neighbourhoods in the Q1 category represent the smallest number of neighbourhoods that together contain a quarter of all high-income (Figure 2) or low-income (Figure 3) occupations in each city. These maps identify how widely distributed a particular group is within the city, and the degree to which they are concentrated in specific locations ${ }^{16}$.

\footnotetext{
*** Figure 2 about here $* * *$
}

*** Figure 3 about here *** 
In New York, people belonging to the high-income occupational group concentrate in the northwest suburban area and increasingly in Manhattan. Meanwhile, the low-income occupational group (Figure 3 ) is highly concentrated in the western part of the Bronx and central Queens. In London, in the 1980s, the high-income group was strongly represented at the edges of the urban region. But since then, this group is increasingly concentrating in the centre of London. While people with highincome occupations were highly concentrated in areas such as Enfield and Bromley in the 1980s, they now live in the central part of London along the River Thames. People with low-income occupations are increasingly residing in neighbourhoods located in the peripheral parts of London, in the west (Hillingdon and Ealing) and northeast (Barking and Dagenham, Newham, and Waltham Forest). Compared with New York, the spatial concentration of the low-income occupational group becomes more visible over time in London. So, despite the overall similar pattern of people with high-income occupations concentrating in the central parts, and people with low-income occupations concentrating in the peripheral parts of the city, the geography of high-income and lowincome occupational group appear to be more polarized in London compared to New York. This is significant as levels of segregation are considerably higher in New York than in London.

Tokyo shows a very clear east-west pattern of segregation. The high-income occupational groups are concentrated in the west of the city while the low-income group mainly resides in the east. Interestingly, this pattern overlaps with the physical geography of Tokyo; people with low income occupations mainly live in the lowland areas in the east, which are at high risk of flooding in case of an earth quake, and people with high income occupations live in the higher areas in the west. However, over time this pattern has become less clear as the Q1 neighbourhoods of the high-income occupational group have become more dispersed, with some new clustering in the south-eastern part of Tokyo. A new concentration emerged from 2000 onwards at the waterfront area around the Chuo and Koto Wards. This area has been redeveloped as part of the urban renaissance policy of the Government. The low-income occupational group continues to have a strong presence in the eastern part of Tokyo, and in the southern Ohta Ward, and has also expanded to the northern parts of the city (a part of the Shinjuku area). What is common for all three cities is that, whereas the global segregation measures reported relatively little change, (Table 2 ) there are substantial changes in the underlying social geography taking place in the three global cities.

Our third research question asked how the geography of the residential distribution of high-income and low-income occupations changed over time. In general, people belonging to the high-income occupational groups tend to concentrate in the most desirable locations within each of the three cities. In New York and London it is clearly visible that since the 1980s, the high-income occupational group has concentrated in the central parts of the city. In New York, the high-income group is concentrating in Manhattan, with further expansions to nearby Brooklyn, and the northwest 
suburban area, a trend that has continued through the study period. In London, in the 1980s, the high-income occupational group was strongly represented at the edges of the urban region, in areas such as Enfield and Bromley. Since then, they have concentrated in the centre of London along the River Thames. Areas of concentrated occupational upgrading include Tower Hamlets and South Hackney in the 2000s, as well as other new developments along the Thames and redevelopments in Camden and Islington ${ }^{7,17}$, where property prices have increased significantly. It is striking that the concentration of the high-income group in the central areas of New York and London coincided with a sharp increase in the share of the high-income occupational group, and an overall trend of professionalization of the workforce. For London, Hamnett ${ }^{18}$ explains this in part by a significant upwards shift in the perceived desirability of East London as a place to buy by an increasingly professional workforce, and a marked increase in demand in East London that has not been met by increased housing supply.

In Tokyo, the high-income occupational group has consistently been concentrated in the western part of the city, which includes inner city neighbourhoods. This residential pattern is strongly related to the physical geography of Tokyo, with people belonging to the high-income group residing in those areas that are elevated above the sea level, and less at risk of flooding. However, in recent decades, people with high-income occupations have also moved to the harbour area in the eastern part of the city, where expensive high-rise apartments are developed. The relatively stable residential geography of occupations in Tokyo is also related to the phenomenon of vertical segregation, which has also be observed in Southern Europe ${ }^{19-21}$. As a result, neighbourhoods are relatively mixed by income, but higher income groups live on higher floor levels than lower income groups.

The residential pattern of the low-income occupational group is almost the inverse of where the high-income groups live. In Tokyo, the low-income occupational group lives concentrated in the eastern parts of the city (the low lands), and despite some spatial dispersal of the group to the northwestern parts of the city, the pattern is remarkably stable over time. In New York and London the concentration of the low-income occupational group has decreased in the most central areas, and increased in the more peripheral areas. In New York individuals belonging to the low-income occupational group have concentrated in the western part of the Bronx and central Queens, and in London in the west (Hillingdon and Ealing) and northeast (Barking and Dagenham, Newham, and Waltham Forest). In both London and New York, some of the low-income concentrations overlap with high concentrations of racial and ethnic minority groups, such as in the northern part of Brooklyn and on both sides of the Harlem River, ranging from north Manhattan to south-eastern Bronx. 


\section{Discussion}

Since Sassen's ${ }^{1}$ work on occupational structure change, and the accompanying debates on polarization and professionalization trends, relatively little attention has been paid to the spatial footprint of occupational structure change in global cities. This study investigated long-term changes in the occupational structures, levels of residential segregation, and the social geographies of income-based occupational groups in New York, London and Tokyo, the three global cities originally studied by Saskia Sassen ${ }^{1,2}$. We found four regularities that characterize socio-spatial change in our three case study cities: (1) professionalization of the workforce is the main trend of occupational structure change in all three cities; (2) occupational change is bigger than city-wide change in levels of residential segregation between occupational groups; (3) professionalization in the occupational structure tends to be associated with lower city-wide levels of segregation; (4) changes in the geography of segregation of occupational groups are bigger than changes in the city-wide levels of segregation between occupational groups.

Although the dominant trend is one of professionalization, and New York and London have converged to a similar occupational structure since the 1980s, there is no convergence towards a universal outcome of socio-spatial change in global cities. All three cities are shaped by globalisation, but the regularities found are also shaped by city-specific contextual factors that lead to different outcomes of occupational change, residential segregation between occupational groups and how occupational change and residential segregation are linked; there are multiple contextual forces that lead to distinct trajectories of occupational and residential changes in New York, London and Tokyo.

The results of our analyses provide support to Hamnett's claim ${ }^{3,4}$ that social polarization might not be a universal feature of occupational structure change in global cities as initially predicted by Sassen. Our findings demonstrate that the occupational structure of all three cities report a consistent trend of professionalization of the workforce over the last three decades. Only between 2000/1 and 2010/11 there seems to be a small increase in the share of low-income occupations in both New York and London, which in combination with a growth in the share of high-income occupations, could signal marginal polarization. The increase in the share of low-income occupations may be related to immigration. As the share of high-income occupations increases, demand for lowincome jobs is met by immigrants, and as a consequence, immigrants tend to be overrepresented in those jobs 22,23 . As a consequence, a "polarized" or "dual" labour market may emerge with migrants employed in jobs with lower pay and lower social security, and natives employed in jobs with higher pay and higher social security ${ }^{1,2,24,25}$. By contrast, Tokyo has experienced very little 
immigration for abroad, and Tokyo also shows relatively little growth in the share of high-income occupations, and a consistent drop in the share of low-income occupations.

When comparing changes in the occupational structures and segregation levels in the three cities, an important regularity seems to emerge: professionalization of the workforce tends to come along with lower levels of residential segregation between occupational groups. This finding is reinforced by the fact that the small increase in the share of low-income occupations between 2000/1 and 2010/11 in New York and Tokyo coincides with an increase in the level of residential segregation. This could suggest that polarization is related to higher levels of residential segregation, but based on only one year of data with a small increase in the share of low-income workers it is not possible to draw hard conclusions on this. Despite the common trend of professionalization, there are marked differences in the level of segregation between the three cities. The level of segregation is the highest in New York and the lowest in Tokyo. These differences are rooted in the history of these cities, but are also likely to be related to their occupational structures. Already in the 1980s New York had a relatively high share of high-income workers, while Tokyo always had the lowest share of high-income workers. A close look at the social geography of the cities can give more insight in the changing socio-spatial patterns.

Significantly, the observed changes in the social geography of where different income-based occupational groups live, appear to be more substantial than the changes observed in the measures of segregation. Although levels of segregation have changed only a little, the spatial organization of households with different socio-economic status has changed a lot, showing two ongoing urban megatrends: the gentrification of inner city neighbourhoods and the suburbanization of poverty ${ }^{26}$. Both of these megatrends - moves of high-income households to formerly low-income areas, and the subsequent push of low-income households towards the urban peripheries - initially contribute to the segregation paradox. The professionalization of the workforce leads to increasing shares of high-income workers, and these high-income workers have developed a preference for living in central areas of cities, and this leads to more social mixing in centrally located urban neighbourhoods, and hence, as we see in our data, dropping levels of residential segregation. However, this mixing is likely to be temporary, as with time, the extent of neighbourhood change in some central city neighbourhoods becomes so dramatic that it has been labelled as supergentrification ${ }^{27,28}$, referring to the continued influx of wealthy people into inner city and waterfront $\operatorname{areas}^{14,29,30}$; the initial social mixing gives way to over-representation of high-income occupational groups in the neighbourhoods they settle. Such processes of super-gentrification have led to a situation where neighbourhoods perceived as more attractive in the central parts of the city have also become beyond the reach of middle-income households. 
There are several interrelated mechanisms that connect changes in the occupational structure with changes in socio-economic segregation within a city ${ }^{31}$. With a changing occupational structure in an urban region, the (purchasing) power balance between income groups also will change. An increase in the size of the high-income occupational group will (all other things being equal) lead to increasing real estate prices in the most desirable locations, with spill-over effects to neighbouring areas. As locational preferences change, higher income households have moved to central areas, pushing lower income households to lower cost areas at some distance. The globalization-related increase of tourists and new forms of housing commodification, such as short-term renting, further contributes to the differential residential mobility of households with different incomes by boosting the real estate prices in the central parts of the cities ${ }^{32}$. At the same time, demographic processes, such as population shrinkage or growth, and in situ upward and downward social mobility are also affecting the population composition in different types of neighbourhoods. Migration from outside the region and abroad often reinforces existing patterns, with high-income immigrants moving to expensive areas, and low-income immigrants entering areas offering lower cost housing. Generally, high levels of international immigration are related to higher levels of social polarization and higher levels of residential segregation.

Although there are similarities in mechanisms, processes and outcomes in global cities, there is no such thing as a single global city model, as local variation produces strongly contextualized outcomes of urban socio-spatial change ${ }^{9,10,33}$. In explaining occupational change, residential segregation between occupational groups and how occupational change and residential segregation are linked, government policy plays an important role, especially policies related to labour and housing markets and immigration. Both national and city level policies can increase or decrease income inequality, and the effects of income inequality between occupational groups on residential segregation between occupational groups ${ }^{34}$. High levels of income inequality will make it more difficult for lowincome households to move to better neighbourhoods, thus reinforcing patterns of residential inequality ${ }^{35}$. Where the US is a classic example of a liberal welfare regime, and the UK represents a more mixed model ${ }^{36}$, Japan has strong governmental influence which seeks to maintain low levels of inequality. This is reflected in the Gini Index, which is the lowest in Tokyo $\left(0.33^{37}\right)$, followed by London $\left(0.44^{38}\right)$, and New York $\left(0.55^{39}\right)$. In fact, Tokyo is the biggest outlier among global cities by being among the wealthiest, but also one of the most equal, cities in terms of income distribution ${ }^{38}$.

Public policy does not just influence income inequality, but also the supply of different types of housing and their spatial configuration. Tokyo is not only one of the most equal global cities in terms of income, but it is also one of the least segregated global cities with mixed housing options in different parts of the city. This is related to government policy to promote urban renewal in Tokyo since the 1980 s, aiming to facilitate economic growth by the central government ${ }^{40}$. Although actively 
deregulating city planning, stimulating redevelopment through private investments, and liberalizing labour and housing markets are part of the state-led urban renewal policy in Tokyo, an implicit control of the state has remained intact ${ }^{41,42}$. For example, through strict labour market regulations and restrictions on immigration to fill low-income jobs.

Earlier studies have suggested that immigration is an important factor for understanding both occupational structure change and residential segregation ${ }^{43}$. Under strong state control, Tokyo has experienced the lowest level of immigration compared to the other two cities. In high-immigration cities, such as New York and London, social and ethnic inequalities increasingly tend to overlap, providing a basis for what Andersson and Kährik ${ }^{44}$ call 'eth-class' segregation. In London, this overlap is related to the ethnic structure of housing tenures; Hamnett and Butler ${ }^{45}$ showed that ethnic minorities in London are becoming increasingly concentrated in council and social housing, which leads to their residential concentration in certain neighbourhoods. In many West European cities, growing immigration is an important driving force of increasing residential segregation between occupational and income groups ${ }^{46}$. In US cities, both immigration as well as historically formed and slowly changing ethnic and racial structures shape occupational structures and segregation levels ${ }^{47}$. While between 1981 and 2011 the share of foreign-born residents increased in New York and London from 24 percent to 37 percent, and 18 percent to 37 percent respectively, the share of residents with non-Japanese citizenship was only still 4 percent in Tokyo in 2010. Strict policies limit the in-migration of low-skilled workers to $\mathrm{Japan}^{48}$, while the in-flow of such workers are a major cause of residential segregation in European capital cities ${ }^{43}$. In the US context, Maloutas and Fujita ${ }^{10}$ observe that the growth of social and spatial polarization is partly a result of a strong interplay between social and racial inequalities.

Despite important new insights provided by our analysis of residential segregation between incomebased occupational groups, a note on limitations to our study should be made. Ideally, the study would have been based on detailed income data for small neighbourhoods or census tracts, but such data are not available for our three cities. We therefore had to use occupational data from the census. Because the income of occupations can change over time, and because the incomes of occupations can differ between cities, we combined occupational data from the census with income data from surveys. We have provided a detailed and transparent account of how we linked occupational data and income data, and how we classified occupations to the high-income, middleincome and low-income occupational groups (see the methods section and the Supplementary Methods section). Since money buys choice, focusing on income helps to better understand the changes in residential segregation compared to occupation-only based studies of residential segregation. But the linking of income and occupational data has two limitations. First, the census and the income surveys use relatively broad occupational categories, which means that our strategy 
does not allow to take into account the variation of income within occupational categories. Second, our strategy leads to changing of some occupations between middle-income and low-income groups as the relative income hierarchy of occupational groups may change in time. By comparison it is rare that occupations move into or out of the high-income group and consequently the results for highincome occupations are more consistent. Although our approach is not without problems, we are confident that the trends we see in the data are robust. To support this, we have provided analyses using occupational groups based on occupational data only (see the Supplementary Figure 3 and the Supplementary Methods). Comparing these with the analyses of income-based occupational groups shows very similar patterns and trends over time, although quantitatively there are differences.

As a final remark, in her work on London, New York and Tokyo, Sassen ${ }^{1,2}$ hypothesized that the polarization of occupational structures in global cities may lead to increasing levels of residential segregation by income. First of all, in our study we found no evidence for the polarization thesis; in fact, we found strong and consistent evidence for professionalization of the occupational structure in all three cities. Between 1980 and 2010 in all three cities the share of high-income occupations increased, and the share of low-income occupations decreased. Between 2000/1 and 2010/11 we found that in New York and London the share of low-income occupations increased somewhat again, which hints at polarization, but further releases of the decennial censuses are needed to confirm this. Second, we found that, generally speaking, professionalization coincides with reducing levels of residential segregation. We found that changes in levels of residential segregation were more modest than changes in occupational structures. Occupational structure change is not the only factor affecting levels of segregation. The regularities of how occupational change takes place and shapes city-wide levels of residential segregation relate to contextual factors such as national and urban policies towards immigration, labour market, housing, etc. Despite relatively minor changes in levels of segregation, we found that the professionalization of the workforce coincides with large changes in the social geography of the three cities. In New York and London, and to a much lesser extend in Tokyo, two ongoing megatrends are characterizing urban change: gentrification of innercity neighbourhoods and suburbanization of poverty. An increasing share of high-income workers has a profound and spatially polarizing effect on the social geography of cities.

\section{Methods}

Ideally, this study would use detailed income data for small neighbourhoods or census tracts, but unfortunately census data for London, New York and Tokyo do not include income. However, censuses do include occupational information, and this information has been extensively used in comparative studies on socio-economic residential segregation ${ }^{9}$. Occupations in census data are classified using the International Standard Classification of Occupations ISCO-88. In this classification 
occupational categories are broadly ordered based on occupational status and the complexity of tasks involved in the jobs. Typically, managers and professionals are classified as the top occupational group, administrative, skilled, sales, non-manual technician, and security occupations are classified as the middle occupational group, and finally service, manual, and semi-skilled occupations are classified as the bottom occupational group. Although there is a strong correlation between occupation and income, this relationship is not consistent. Generally, the higher occupational categories (managers and professionals) have high incomes, and the lower occupational categories (low-skill service and manual jobs) have low incomes. But occupations in the middle categories show more income variation. Moreover, the relationship between occupation and income is likely to differ between countries, and over time occupations might go up (or down) in income, relative to other occupations. Not taking into account such differences and changes over time could be problematic as we are interested in the spatial patterning of occupational categories in cities, and it is income which gives access to good neighbourhoods and good housing, not occupation.

In order to overcome these problems and to get a better comparative insight in residential segregation in the three global cities studied by Sassen, we do not simply use occupational categories, but we have developed an income-based ranking of occupations. This approach, which adds incomes to occupations, reflects that some occupations have higher or lower incomes than their ranking by occupational status would suggest. And the approach takes into account that, over time, the income of occupations can change because an occupational category might move up or down in income relative to other occupational categories.

\section{Occupational data}

Fine-grained occupational data for each city were obtained from national population censuses (the US Census Bureau for New York; the Office for National Statistics for London; and the Statistics Bureau, Ministry of Internal Affairs and Communications for Tokyo). We collected data from publicly available sources for each decennial census period from 1980 to 2010 for the US, with comparable information for the UK for the 1981 to 2011 period. From 2010, data on occupation were not collected by the decennial long form of the US census and therefore occupational data from the American Community Survey 5-year estimates (2006-2010) were used. For Tokyo, the population census is conducted every five years, and for reasons of comparability data was used from the 1980, 1990,2000 , and 2010 censuses as these matched most closely with what was available for the US and the UK. Although the census year differed slightly between countries, we refer to our study period as 1980-2011 in this paper. From the census data we have used spatially aggregated occupations following the International Standard Classification of Occupations ISCO-88. For each census year, the occupational categories were classified into high-income, middle-income and low- 
income occupational groups based on their income levels (see next section for more details). In doing so, we have excluded a small number of agricultural, forestry and fishery workers, as well as unclassified workers, from the analysis.

There are several limitations to the census data used. Occupational classifications differ somewhat between the three cities and there are also some changes over time in the classifications. There was a major change in the occupational categories in the US and Japan between 1990 and 2000, and between 2005 and 2010. In the UK the categories changed every census year, and for the 1981 UK census occupational status was not available, so the variable "socio-economic group" was used. A detailed overview of occupational categories for each city and year is available for reference in Supplementary Figure 1.

\section{Income data}

To combine occupational data with income data, we rely on survey data which links occupations to incomes, for each city, and each year of analysis. We have sourced the best possible data for this task, but nevertheless the income data was not completely comparable between cities and over time. The definition of income differs somewhat in different data sources (hourly, daily, weekly or annual income and reported as occupational mean or median income), and the income data were not always available for the same metropolitan boundaries as the census data. See Supplementary Table 1 for more detail on the income data used. For New York City, we used the median weekly earnings at the national level from the Current Population Survey 1983 and 1989, which are derived from Mellor ${ }^{49}$ and Ilg and Haugen ${ }^{50}$ (2000), respectively. Additionally, we used the Occupational Employment Statistics to obtain the mean hourly wage by occupation for New York State for the 2000-2010 periods. For London, our income data are based on the New Earnings Survey (NES) and the Annual Survey of Hours and Earnings (ASHE). The nationwide NES occupational tables cited by Routh ${ }^{51}$ provide average annual pay as of 1979 by occupation. The NES 1990 and the ASHE 20002010 provide median gross weekly pay for full-time employees. The NES 1979 and 1990 data are nationwide, and the later data is for the London region. Finally, for Tokyo we obtained income data from the Employment Status Survey $(1982,1992,2002$, and 2012) for Tokyo Prefecture, via tailormade aggregations from the Japanese Statistic Bureau. Using these datasets, we calculated the mean daily male wage for occupational categories, by dividing the total amount of annual income of employees by the total number of annual days worked.

\section{Defining neighbourhoods}

Obtaining comparable geographies (i.e., the spatial units of aggregation) for the three cities for four time periods was also a challenging task. The aim was to obtain geographies which were both as consistent as possible over time within a city and also comparable between cities. Census Tracts 
were used in New York, Lower Layer Super Output Areas (LSOAs) in London, and both Cho districts and $500 \mathrm{~m}$ by $500 \mathrm{~m}$ grid cells in Tokyo. While the US census data provides almost consistentthrough-time census tracts since 1980, the data for London and Tokyo were more challenging. For London, LSOAs are only available for the 2001 and 2011 censuses. For earlier censuses smaller enumeration districts (EDs) were available so, to solve this issue, we created consistent LSOAs for the whole period with EDs for 1981 and 1991 mapped on these consistent LSOAs according to the overlapping areas. Whilst this approach does not provide perfect correspondence between the ED and LSOA boundaries (some interpolation is required) it allows a consistent set of areas to be produced. It should also be noted that the 1981 and 1991 data are based on a 10 percent sample of the population. In Tokyo, there are two types of small area data available, although the occupational data was not released at Cho district level for 1990 . For the $500 \mathrm{~m}$ grid square units, direct comparison over time is difficult because the geographic coordinate system changed in 2001 . We therefore use Cho district data for 2000 and 2010, and grid data for 1980 and 1990. As with the UK data, this requires a compromise, but the trade-off is that we have a longer time series to get insight into changing levels of socio-economic segregation. Throughout the paper we use the term 'neighbourhood' to characterize the smallest spatial units used.

For the analyses we have defined a city region for each of the three cities. We defined New York City as including five boroughs, Manhattan, Brooklyn, Queens, the Bronx and Staten Island. London was defined to include the Greater London County consisting of 32 boroughs. And Tokyo is defined based on the so-called special wards area, which is composed of 23 wards. Maps of each of the areas, and including authority names, are available in Supplementary Figure 2.

\section{Creating income-based occupational groups}

We have assigned occupational categories from the census data to high-income, middle-income and low-income groups based on income and occupational data from surveys carried out at roughly the same time as the census for each country. This approach results in occupational groups which are more coherent in terms of income compared to an approach which only takes occupational status into account. Previous studies ${ }^{9}$, have assigned occupations to different occupational groups based on only occupational status from the ISCO classifications. The cut-off points between the different occupational status groups were based on the status and complexity of the jobs. That this approach is problematic, can be illustrated with the example of 'Clerical and Secretarial Occupations' in London in 1991. According to the occupational status ranking, these occupations are the fourth in the ranking, and based on an occupations only classification these would be classified as middle status or income occupations (see also ${ }^{9}$ ). However, when taking income into account one can see in Supplementary Figure 1 that 'Clerical and Secretarial Occupations' are actually the lowest paid of all occupational categories. Using our approach, we therefore classify these occupations as low-income 
occupations. To assess to what extent the occupations-only approach (see Supplementary Figure 3) and our approach of combining income and occupational data (see Figure 1 in this paper) lead to different outcomes, we compared the two approaches in the Supplementary Methods section. Based on this assessment we conclude that although there are important differences between the two approaches, qualitatively the patterns found are very similar, both in terms of the sizes of the occupational status groups, and in terms of the measured levels of segregation.

To assign occupational status groups to the high-income, middle-income and low-income groups we initially ranked occupations by income, as in our approach it is income that determines the order of occupations, not occupational status (see Supplementary Figure 1). The cut-off point between highincome, middle-income and low-income occupations is determined by a combination of income and occupational status. This is easiest explained for the high-income occupations. In all three cities and in all years the managers and professionals have the highest incomes. As these are also the highest status occupations, we have assigned them consistently to the high-income occupations, which is in line with the approach which only uses occupational status (see the Supplementary Methods section). If over time the number of jobs in the high-income occupations increases, this means that according to the ISCO classification there are more jobs in this category, reflecting a growth in the number of top jobs.

Assigning occupations to either the middle-income and the low-income groups was less straightforward because the income range at the lower end of the distribution is more compressed $^{52}$, and because the occupational categories used in the income data are sometimes less detailed than what was available in the census (due to smaller sample sizes). A good example is New York in 1990 where the income data is clearly less detailed than the occupational data (see Supplementary Figure 1). In these cases, we have assigned occupations to either the middle-income or the low-income groups based on more detailed occupational categories from the previous or the next census. In deciding the cut-off between low- and middle-income jobs we tried to achieve a minimum possible switching of the occupations between income-groups on the one hand, and to we took into account occupational status on the other hand. For example, in Tokyo in 1980, the production process and related workers, and the service workers clearly earn the least, and these are also the least skilled manual jobs. Hence we assigned them to the low-income group, which also reflects the occupational status of the jobs. It is clear from Supplementary Figure 1 that in distinguishing between low- and middle-income jobs a strictly quantitative approach is not suitable. Therefore, for each city and each year we have made careful considerations when assigning occupations to the middle-income or low-income categories, based on income levels, occupational status, and consistency over time within cities. Below we explain how we categorized occupations in middle-income and low-income groups for each city. 
From 1991 the UK census data adopted occupational classifications comparable to the US and Japan, but the 1981 classifications are substantively different. For the 1981 data we adopted a cutting point for mid- and low-income earners between "Semi-skilled manual workers" and "Personal service workers". Although the income data did not allow us to derive separate income measures for these two groups, we elected to categorize the "Personal service workers" as low-income based on income data for other census years. Also, when using only occupational status information, personal service workers are often categorized as low status, and semi-skilled workers as middle status jobs $\left(\right.$ see also ${ }^{9}$ ). For 1991, the cutting point runs between "Plant and machine operatives" and "Sales occupations" to avoid switching. Although the income differences between those two groups are not very large at the beginning of the study period, the differences become more marked during the later censuses. In later census years the sales occupations are among the lowest paid in the UK, and hence we classified them as low-income also in 1991. For 2001 and 2011 the cutting point is between "Administrative and secretarial occupations" and "Personal service occupations". This decision was based on the fact that administrative and secretarial occupations are ranked fourth in terms of occupational status according to the ISCO, and they clearly earn much more than the personal service occupations. The "Administrative and secretarial occupations" are an interesting group as in the earlier years they were among the lowest paid, while in more recent years they had more middle-income levels.

For Tokyo, the cutting point between middle and low-income occupations runs between "Clerical worker" and "Production process and related workers" in 1980, based on both income and skill levels required. In 1990 and 2000, the cutting point runs between "Transport and communication workers" and "Production process and related workers" for similar reasons. Although "Transport and machine operation workers" earn slightly less than "Construction and mining workers" in 2020, they are labelled as middle-income as we follow the definition used in the previous period in order to be as consistent as possible.

Categorizing occupations by income was most challenging New York. This was partly due to the reordering of occupations between years based on their income levels, and partly because in 1991 incomes were only available for rather broad occupational categories. In 1980, "Machine operators, assemblers, and inspectors" are categorized as low-income occupations, and "Administrative support occupations, including clerical" as middle-income occupations, even though their income levels are very similar. We decided to do so to avoid switching and keeping the consistency of classification with 1990, when administrative and clerical occupations had relatively high incomes. The cut-off between middle-income and low-income and status occupations was made based on the skill level and status of the occupational categories. Since the New York income data for 1990 
has very broad occupational categories, we decided to take into account information from the previous and the next census years to decide how to categorize more detailed occupational categories. "Machine operators, assemblers, and inspectors" and "Handlers, equipment cleaners, helpers and laborers" were categorized as low-income occupations. This was done despite the fact that the broad occupational group they fall into had a relatively high-income. Likewise, "Protective service occupations" were categorized as middle-income occupations, despite the fact that their broad occupational category has relatively low-incomes. But in the previous and next census year, these occupations fall clearly into the middle-income group, hence our choice. The classification is more straightforward for 2000 and 2010, and the cut-off point between middle-income and lowincome occupations runs between "Transportation and material moving occupations" and "Production occupations".

From this detailed account it is clear that, although our approach better reflects the incomes of different occupational categories, it also has its limitations. These are discussed in more detail in the conclusions of this paper.

\section{Analytical Approach}

The empirical analysis of this paper is divided in three parts. First, we investigate changes in the occupational structure based on the three broad high-income, middle-income and low-income occupational groups. Second, to examine residential segregation between income-based occupational groups, two classic segregation measures are calculated: the Index of Dissimilarity $(I D)^{53}$, and the Multi-group Dissimilarity Index (MDI) ${ }^{54}$. The ID value ranges from 0 to 1 , and indicate either the share of the high- or low-income occupational group members who need to change their neighbourhood of residence in order to the achieve a similar distribution of both groups across neighbourhoods within a city. The MDI value characterizes the spatial distribution of more than two groups, in our case high-income, middle-income and low-income occupational groups. Its value also ranges from 0 to 1 , with a higher value representing greater levels of residential segregation.

The third part of our analysis focusses on better understanding the changing social geography of the three cities. We map the residential concentration of the high-income and low-income occupational groups. All neighbourhoods in a city are classified into four different categories (Q1-Q4), which comprises the quartiles of the distribution for the absolute number of the group's members, which are then mapped ${ }^{16}$. For example, to examine the residential concentration of the high-income occupations, all neighbourhoods are ordered based on the absolute number of people in this group living in each neighbourhood. All neighbourhoods which add up to a quarter of the top category living there are labelled Q1. In a similar manner, the neighbourhoods where the second, third and fourth quarter of the high-income occupations reside are labelled Q2, Q3, and Q4 respectively. The 
fewer neighbourhoods there are in the Q1 category, the more concentrated this group is in that particular city. The same method is used to investigate the residential concentration of the lowincome occupational group.

\section{Data availability}

The main data used in our study is national census data for the US, Japan and the UK. The data for each country is publicly available and owned by each respective government (the US Census Bureau for New York; the Office for National Statistics for London; and the Statistics Bureau, Ministry of Internal Affairs and Communications for Tokyo). All data can be obtained at the original source, below find detailed information for each city.

Tokyo: We used national census data for Tokyo for the years 1980, 1990, 2000 and 2010. The 1980 and 1990 data is available from Sinfonica (Statistical Information Institute for Consulting and Analysis for which you need to pay a fee): http://www.sinfonica.or.jp/datalist/index.html. The 2000 and 2010 data is available through the e-Stat website by Statistics Bureau of Japan: https://www.estat.go.jp/gis/statmap-search?page=1\&type $=1 \&$ toukeiCode $=00200521$.

London: We used national census data for London for the years 1981, 1991, 2001, and 2011. The data for the 3 first years is available from the Casweb website (UK Data Service) by Economic and Social Research Council: http://casweb.ukdataservice.ac.uk/. Data for 2011 is available through the Nomis website by the Office of National Statistics https://www.nomisweb.co.uk/ or from http://infuse.ukdataservice.ac.uk/.

New York: We used national census data for New York for the years 1980, 1990, 2000 and 2010. The 1980 and 1990 data is available through the Social Explorer website by Social Explorer Inc: https://www.socialexplorer.com/. The 2000 and 2010 data is available on the American FactFinder website by the US Census Bureau: https://www.census.gov/data/data-tools/americanfactfinder.html.

In addition to the census data, we have used nationally representative survey data which includes information on income levels for occupations for each of the three countries and for multiple periods. This data is publicly available.

For New York City, we used data at the national level from the Current Population Survey 1983 and 1989, which are derived from Mellor (1985) and IIg \& Haugen (2000), respectively. Additionally, we 
used the Occupational Employment Statistics to obtain mean hourly wage by occupation for New York State for the 2000-2010 the periods.

1983: Mellor, E.F. (1985) Weekly earnings in 1983: a look at more than 200 occupations. Monthly Labor Review, January 1985, 54-59. https://www.bls.gov/opub/mlr/1985/01/rpt1full.pdf

1989: Ilg, R.E. and S.E. Haugen (2000) Earnings and Employment Trends in the 1990s. Monthly Labor Review, March 2000, 21-33. https://www.bls.gov/opub/mlr/2000/03/art2full.pdf

2000: https://www.bls.gov/oes/tables.htm

2010: https://www.bls.gov/oes/tables.htm

For London we used data from the New Earnings Survey (NES) and the Annual Survey of Hours and Earnings (ASHE). The nationwide NES occupational tables cited from Routh (1980) provides average annual pay as of 1979 by occupation. The NES 1990 and the ASHE 2000-2010 provide median gross weekly pay for full-time employees.

1979: 1Routh, G. (1980) Occupation and Pay in Great Britain 1906-79 (second edition). London: Macmillan.

1990: https://www.ons.gov.uk/employmentandlabourmarket/peopleinwork/earningsandworkinghours/datalist

2000: https://www.ons.gov.uk/employmentandlabourmarket/peopleinwork/earningsandworkinghours/datalist

2010: https://www.ons.gov.uk/employmentandlabourmarket/peopleinwork/earningsandworkinghours/datalist

Finally, for Tokyo, we used the Employment Status Survey $(1982,1992,2002,2012)$ which was obtained by requesting tailor-made aggregations from the Statistic Bureau.

\section{References}

1 Sassen, S. The global city. (Wiley, 1991).

2 Sassen, S. The global city: New York, London, Tokyo 2nd edition. (Princeton University Press, 2001).

3 Hamnett, C. Social polarisation in global cities: theory and evidence. Urban studies 31, 401-424 (1994).

4 Hamnett, C. Socio-economic change in London: professionalization not polarization. Built Environment 20, 192-203 (1994).

5 Butler, T., Hamnett, C. \& Ramsden, M. Inward and upward: marking out social class change in London, 1981-2001. Urban Studies 45, 67-88 (2008).

6 Davidson, M. \& Wyly, E. Same but different: Within London's 'static' class structure and the missing antagonism. $c / T Y 19,247-257$ (2015).

7 Johnston, R. \& Manley, D. London: A dividing city, 2001-11? City 18 (2014). 

Seoul. Urban Studies 37, 2167-2195 (2000).

Tammaru, T., Marcińczak, S., van Ham, M. \& Musterd, S. Socio-Economic Segregation in European Capital Cities: East Meets West. (2016).

Maloutas, T. \& Fujita, K. Residential Segregation in Comparative Perspective. Making Sense of Contextual Diversity. (Ashgate, Farnham, 2012).

Musterd, S. \& Ostendorf, W. The changing distribution of incomes in Dutch cities: myth and reality. GeoJournal 46, 29-38 (1998).

12 Marcińczak, S. et al. Patterns of socioeconomic segre-gation in the capital cities of fasttrack reforming postsocialist countries. Annals of the Association of American Geographers 105, 183-202 (2015).

13 Hulchanski, J. D. The Three Cities Within Toronto: Income Polarization Among Toronto's Neighbourhoods, 1970-2005. (University of Toronto, 2010).

14 Atkinson, R. Limited exposure: Social concealment, mobility and engagement with public space by the super-rich in London. Environment and Planning A: Economy and Space 48, 1302-1307 (2016).

15 Atkinson, R. \& Ho, H.-K. in Research Handbook on Urban Segregation (ed S Musterd) (Edward Elgar, 2019).

16 Johnston, R., Jones, K., Manley, D. \& Owen, D. Macro-scale stability with micro-scale diversity: modelling changing ethnic minority residential segregation-London 20012011. Transactions of the Institute of British Geographers 41, 389-402 (2016).

17 Cunningham, N. \& Savage, M. An intensifying and elite city: New geographies of social class and inequality in contemporary London. City, 1-22 (2017).

Hamnett, C. Spatially displaced demand and the changing geography of house prices in London, 1995-2006. Housing Studies 24, 301-320 (2009).

Leal, J. \& Sorando, D. in Socioeconomic segregation in European Capital Cities: East Meets West (eds T Tammaru, S Marcinczak, M van Ham, \& S Musterd) 214-237 (Routledge, 2016).

20 Maloutas, T. in Socio-Economic Segregation in European Capital Cities. East meets West (eds T Tammaru, Szymon Marcińczak, M van Ham, \& S Musterd) 156-185 (Routledge, 2016).

21 Hirayama, Y. in Cities and the Super-rich: Real Estate, Elite Practices and Urban Political Economies (eds R Forrest, D Wissink, \& S.Y Koh) (Palgrave Macmillan, 2016).

22 Kogan, I. New Immigrants - Old Disadvantage Patterns? Labour Market Integration of Recent Immigrants into Germany. International Migration: Special Issue 49, 91-117, doi:10.1111/j.1468-2435.2010.00609.x (2010). 
23 Ruiz, I. \& Vargas-Silva, C. Differences in labour market outcomes between natives, refugees and other migrants in the UK. Journal of Economic Geography 18, 855-885 (2018).

24 Fullin, G. \& Reyneri, E. Immigrants in West European Labour Markets: A Dynamic Approach. International Journal of Comparative Sociology 52 (2011).

25 Doeringer, P. \& Piore, M. Internal Labor Markets and Manpower Analysis. (Mass, 1972).

26 Hochstenbach, C. \& Musterd, S. Gentrification and the suburbanization of poverty: Changing urban geographies through boom and bust periods. Urban Geography 39, 2653 (2018).

27 Lees, L. Super-gentrification: The Case of Brooklyn Heights, New York City. Urban Studies 40, 2487-2492 (2003).

28 Butler, T. \& Lees, L. Super-Gentrification in Barnsbury, London Globalization and Gentrifying Global Elites at the Neighbourhood Level. Transactions of the Institute of British Geographers 31, 467-487 (2006).

29 Beaverstock, J. V., Hubbard, P. \& Short, J. R. Getting away with it? Exposing the geographies of the super-rich. Geoforum 35, 401-407 (2004).

30 Petsimeris, P. \& Rimoldi, S. in Socio-Economic Segregation in European Capital Cities/East-meets West (eds T Tammaru, S Marcinczak, M van Ham, \& S Musterd) 186213 (Routledge, 2016).

31 Tammaru, T., van Ham, M., Janssen, H., Marcinczak, S. \& Aunap, R. Relationship between income inequality and residential segregation between socioeconomic groups. Regional Studies, 1-12 (2019).

32 Guttentag, D., Smith, S., Potwarka, L. \& Havitz, M. Why Tourists Choose Airbnb: A Motivation-Based Segmentation Study. Journal of Travel Research 57, 342-359 (2018).

33 Van Kempen, R. \& Murie, A. The new divided city: changing patterns in European cities. Tijdschrift voor Economische en Sociale Geografie 100, 377-398 (2009).

34 Fujita, K. \& Hill, R. C. in Residential segregation in comparative perspective: Making sense of contextual diversity (eds T Maloutas \& K Fujita) 54-86 (Ashgate, 2012).

35 Nieuwenhuis, J., Tammaru, T., Van Ham, M., Hedman, L. \& Manley, D. Does segregation reduce socio-spatial mobility? Evidence from four European countries with different inequality and segregation contexts. Urban Studies, 1-22 (2019).

36 Esping-Andersen, G. The Three Worlds of Welfare Capitalism. (Princeton University Press, 1990).

37 UN-Habitat. State of the World's Cities 2008/2009. Harmonious cities., (Earthscan, 2008).

38 Adomaitis, K. The World's Largest Cities Are The Most Unequal. Euromonitor International (2013). 
Gini Index

for New

York,

$N Y$, <http://www.civicdashboards.com/city/new-york-ny-16000US3651000/gini index> (2015).

Hiramoto, S., Katayama, S., Cho, K. \& Matsutani, S. Tokyo's Large-scale Urban Redevelopment Projects and their Processes. 43rd ISOCARP Congress (2007).

Tsukamoto, T. Neoliberalization of the Developmental State: Tokyo's Bottom - Up Politics and State Rescaling in Japan. International Journal of Urban and Regional Research 36, 71-89 (2012).

42 Waley, P. Pencilling Tokyo into the map of neoliberal urbanism. Cities 32, 43-50 (2013).

43 Marcińczak, S., Musterd, S., van Ham, M. \& Tammaru, T. in Socio-economic segregation in European capital cities: East meets West (eds Tiit Tammaru, Szymon Marcińczak, Maarten van Ham, \& Sako Musterd) 358-382 (Routledge, 2016).

44 Andersson, R. \& Kährik, A. in Socio-Economic Segregation in European Capital Cities: East Meets West (eds T Tammaru, S Marcińczak, M Van Ham, \& Musterd; S) 110-131 (Routledge, 2016).

45 Hamnett, C. \& Butler, T. The Changing Ethnic Structure of Housing Tenures in London, 1991-2001. Urban Studies 47, 55-74 (2010).

Musterd, S., Marcińczak, S., van Ham, M. \& Tammaru, T. Socioeconomic segregation in European capital cities. Increasing separation between poor and rich. Urban Geography 38, 1062-1083 (2017).

47 Iceland, J. Race and ethnicity in America. (University of California, 2017).

48 Machimura, T. Symbolic use of globalization in urban politics in Tokyo. International Journal of Urban and Regional Research 22, 183-194 (1998).

49 Mellor, E. F. Weekly earnings in 1983: a look at more than 200 occupations. Monthly Labor Review, 54-59 (1985).

50 Ilg, R. E. \& Haugen, S. E. Earnings and Employment Trends in the 1990s. Monthly Labor Review, 21-33 (2000).

51 Routh, G. Occupation and Pay in Great Britain 1906-79. (Macmillan, 1980).

52 Reardon, S. \& Bischoff, K. Income inequality and income segregation. American Journal of Sociology 116, 1092-1153 (2011).

53 Duncan, O. \& Duncan, B. Residential distribution and occupational stratification. American Journal of Sociology 60, 493-503 (1955).

54 Reardon, S. \& Firebaugh, G. Measures of multi-group segregation. Sociological Methodology 32, 33-67 (2002).

55 Manson, S., Schroeder, J., Van Riper, D. \& Ruggles S. IPUMS National Historical Geographic Information System: Version 14.0 [Database]. Minneapolis, MN: IPUMS (2019). http://doi.org/10.18128/D050.V14.0 

and Postcode Directories, 1980-. [data collection]. UK Data Service. SN: 5819 (2008). http://doi.org/10.5255/UKDA-SN-5819-1

\section{Acknowledgements}

The research leading to these results has received funding from the European Research Council under the European Union's Seventh Framework Program (FP/2007-2013) / ERC Grant Agreement n. 615159 (ERC Consolidator Grant DEPRIVEDHOODS, Socio-spatial inequality, deprived neighbourhoods, and neighbourhood effects), from the Japan Society for the Promotion of Science KAKENHI Grant Number JP17K13584, from the Estonian Research Council (PUT PRG306, Infotechnological Mobility Laboratory, RITA-Ränne), and from TU Delft (visiting professorship of Tiit Tammaru). The funders had no role in study design, data collection and analysis, decision to publish or preparation of the manuscript.

\section{Author contributions}

$M V H, M U, T T, D M$, and $H J$ have equally contributed to the conception of the work, the interpretation of the data, and the drafting of the work. MVH and TT have designed the study and written its conceptual and discussion sections. MU has been responsible for handing the data and executing the analysis and making the figures. $\mathrm{MVH}$, as the corresponding author, has been responsible for the revisions of the manuscript with the help of all other authors.

\section{Competing interests}

The authors declare no competing interests. 


\section{Figures}

\section{Figure 1. Changes of occupational structure}

Three socio-economic groups are classified according to the income level by occupational classification

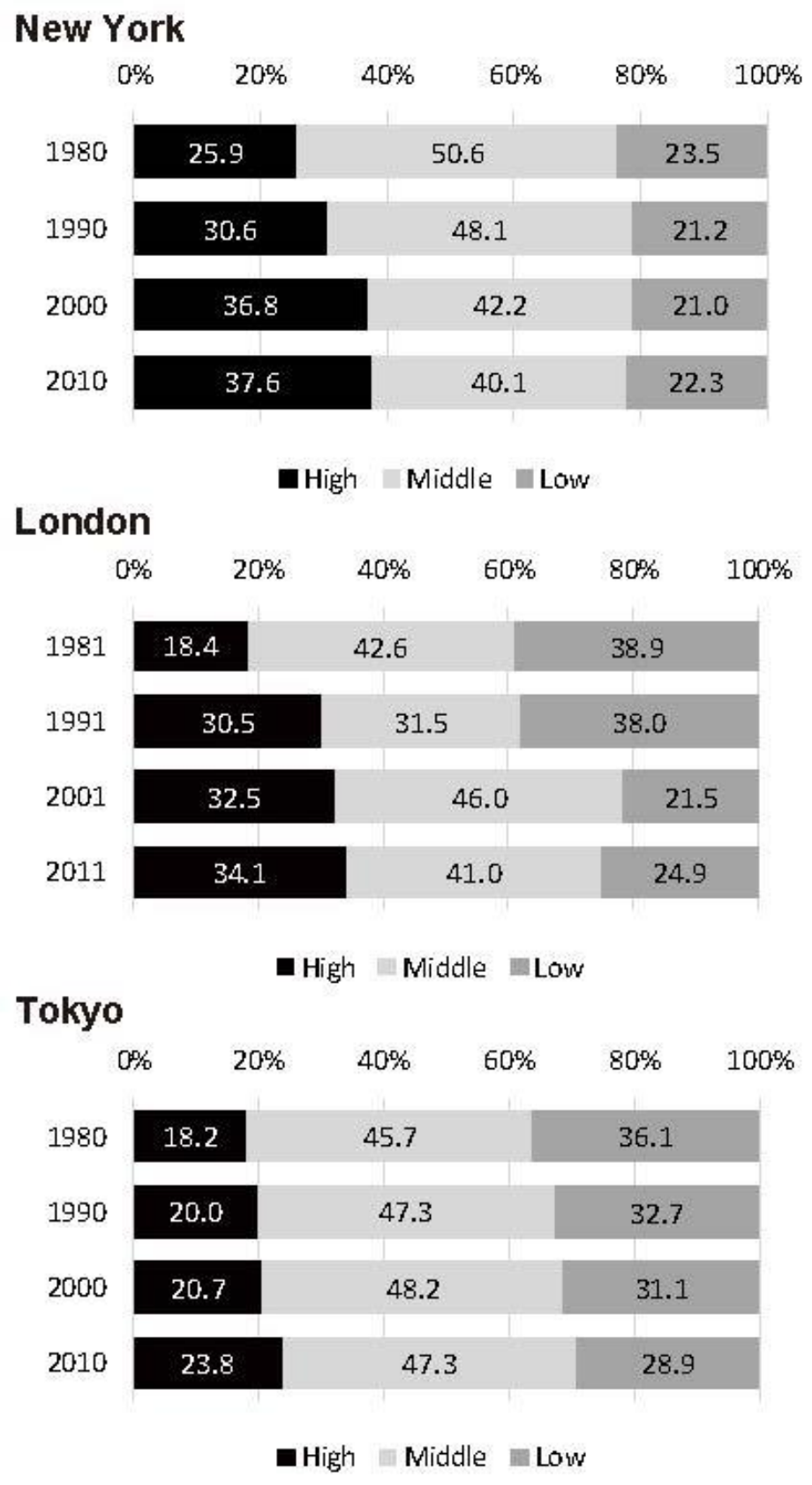




\section{Figure 2. The distribution of the high-income occupational group}

The four group (Q1-Q4) comprise the quartiles of the distribution for the absolute number of the high-income occupations. The colours indicate the neighbourhoods in each quartile. New York: census tracts. London: consistent LSOAs (10\% sample) (1981 / 1991) and LSOAs (2001 / 2011). Tokyo: grid cells (1980 / 1990) and cho districts (2000 / 2010). Maps were created using ArcGIS software by Esri. The 1980 US Census shapefile originates from reference 55. The UK Census shapefiles originate from reference 56. The London map contains National Statistics data (C) Crown copyright and database right 2012 and contains Ordnance Survey data @ Crown copyright and database right 2012.

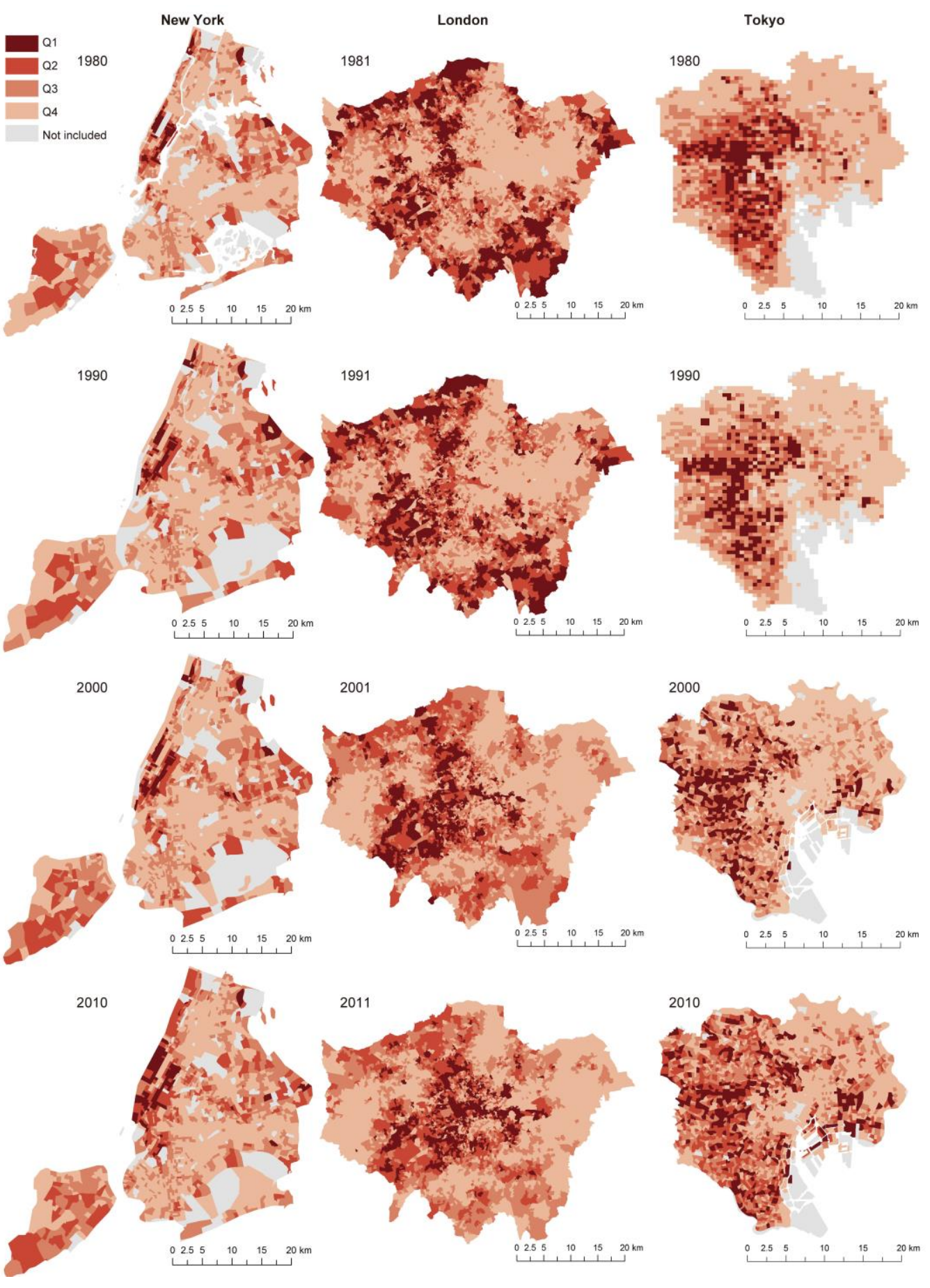




\section{Figure 3. The distribution of the low-income occupational group}

The four group (Q1-Q4) comprise the quartiles of the distribution for the absolute number of the low-income group members. The colours indicate the neighbourhoods in each quartile. New York: census tracts. London: consistent LSOAs (10\% sample) (1981 / 1991) and LSOAs (2001 / 2011). Tokyo: grid cells (1980 / 1990) and cho districts (2000 / 2010). Maps were created using ArcGIS software by Esri. The 1980 US Census shapefile originates from reference 55. The UK Census shapefiles originate from reference 56. The London map contains National Statistics data (C) Crown copyright and database right 2012 and contains Ordnance Survey data @ Crown copyright and database right 2012.

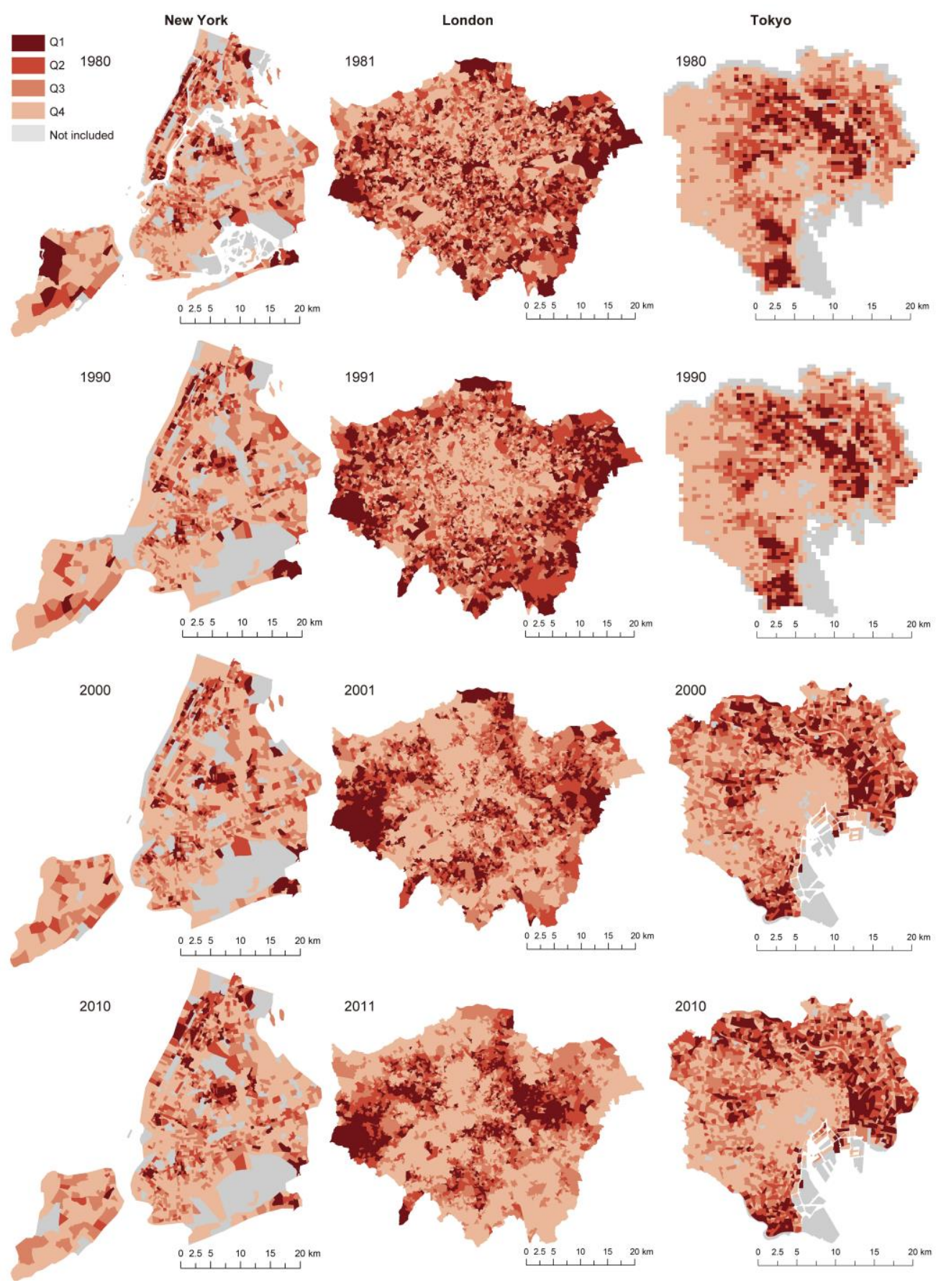




\section{Tables}

Table 1. Index of Dissimilarity (ID) and Multi-group Dissimilarity Index (MDI)

\begin{tabular}{|c|c|c|c|c|c|c|c|c|}
\hline & \multicolumn{4}{|l|}{$I D^{a}$} & \multicolumn{4}{|l|}{$\mathrm{MDI}^{\mathrm{a}}$} \\
\hline & $\begin{array}{l}\text { New York } \\
\text { (CT) }\end{array}$ & $\begin{array}{l}\text { London } \\
\text { (LSOA) }\end{array}$ & $\begin{array}{l}\text { Tokyo } \\
\text { Grid }\end{array}$ & Cho & $\begin{array}{l}\text { New York } \\
\text { (CT) }\end{array}$ & $\begin{array}{l}\text { London } \\
\text { (LSOA) }\end{array}$ & $\begin{array}{l}\text { Tokyo } \\
\text { Grid }\end{array}$ & Cho \\
\hline 1980 & 0.4471 & $0.2645^{b}$ & 0.2720 & - & 0.2605 & $0.1663^{b}$ & 0.1390 & - \\
\hline 1990 & 0.4199 & $0.2375^{b}$ & 0.2613 & - & 0.2466 & $0.1742^{b}$ & 0.1309 & - \\
\hline 2000 & 0.4020 & 0.2952 & 0.2337 & 0.2403 & 0.2545 & 0.1611 & 0.1164 & 0.1220 \\
\hline 2010 & 0.4239 & 0.3062 & - & 0.2347 & 0.2726 & 0.1671 & - & 0.1214 \\
\hline
\end{tabular}

a ID: High and Low, MDI: 3 group (High, Middle and Low).

${ }^{b} 10$ percent sample data. 


\section{SUPPLEMENTARY INFORMATION}

\section{Supplementary Methods}

\section{Occupational status groups based on occupations only}

To supplement the classification based on occupations in combination with income (as used in the main paper), we also explored the use of a standard classification method based on occupational status alone. We have classified occupations as top, middle and bottom occupational status occupations. This classification is based on the ordering of occupations by status as in the International Standard Classification of Occupations ISCO-88. The classification can be found in Supplementary Figure 3. In our classification of top, middle, and bottom occupational status groups we used the ordering of occupations as provided by ISCO, and we made the division between the three groups based on the perceived complexity of the jobs. In our occupation-based classification the top group consists of 'managers' and 'professionals' in all years and in all three cities. The middle group consists of a mix of administrative, skilled, sales, non-manual technician, and security occupations. And the bottom group consists of a mix of service, manual, and semi-skilled occupations. Because of changes in the classification of occupations over time in the census, and because of differences between the three cities we detail the definition of the middle and bottom occupational status groups by city below.

For New York in 1980 and 1990 the middle group consists of 'technicians and related', 'sales', 'administrative support and clerical', and 'protective service'. In 2000 and 2010 the category technicians was not included in the middle group as this category was not available in the classification used. The bottom group includes all the other occupations, including 'personal care and service', and other manual and support occupations. For London in 1980 the middle group consists of 'ancillary workers and artists', 'foremen and supervisors-non manual', 'junior nonmanual workers', and 'own account workers (other than professionals)'. In 1991 the middle group consists of 'associate professional and technical occupations', 'clerical and secretarial occupations', and 'sales occupations'. And in 2001 and 2011 the category 'skilled trades occupations' was added to the middle status group. The bottom group includes all other occupations, including 'personal service', 'plant and machine operatives' and 'manual' and 'unskilled workers'. For Tokyo the middle group consists of 'clerical workers', 'sales workers', and 'security workers' in all years. And the bottom group consists of 'service workers', and a combination of other manual occupations.

In the main paper we have used a classification of occupations based on a combination of occupational status and income (see detailed information on the classification in Supplementary 
Figure 1). We argued that it is important to take income into account, as some occupational categories saw increases or decreases in their income over time, and this likely influences their spatial patterning in cities. The pure occupation based classification in top, middle and bottom status occupations (Supplementary Figure 3), and the income based classification in high, middle and low income occupations (Figure 1 in the main paper) lead to very similar results, but there are also some important differences. The relative size of the top and high group is the same for all time periods and cities as the same categories are used. The differences are in the sizes of the middle groups, and the low income and bottom status groups. For New York the middle group becomes smaller over time in both occupation and income based classifications. But when using the income based classification the middle group is consistently larger in all years. For London the middle group is very similar using both types of classifications, but the group is slightly smaller when using income based classifications in all years. And in Tokyo the middle group is slightly larger when using the income based occupational classification. As a consequence of these differences in the middle group, there are also differences between the occupation based classification and the income based classification regarding the bottom status group and the low income group. In New York the low income group is consistently smaller than the bottom occupational status group. In London the low income group is slightly larger than the bottom occupational group. And in Tokyo the low income group is slightly smaller than the bottom occupational status group.

Despite these differences between the occupation only classification and the income based classification, the patterns observed are very similar. In all three cities the highest income and status group increases in size, but increases most in New York and London. In New York the middle group deceases in size in both classifications, and the bottom group stays relatively stable, following the same pattern. In London the middle group remains similar in size between 1981 and 2011, following the same pattern in the years in between. And in London the bottom group decreases in size in both classifications, following the same pattern in the years in between. Finally, in Tokyo the patterns are very similar for both types of classifications. So where there are some differences in the sizes of the groups, qualitatively the patterns are very similar.

Measuring segregation using occupational status groups based on occupations only, not taking income into account

Supplementary Table 2 presents measures of segregation using the alternative classification of occupations in top, middle and bottom occupational status occupations, based on only occupations, not taking into account income data as used in the main analyses of this paper. The two classifications, based on only occupations, and based on income and occupations, lead to similar patterns of segregation over time, but there are some differences. 
For New York, the income based classification of occupations leads to slightly higher levels of segregation as indicated by both the ID and the MDI. But the pattern over time is very similar for both classifications. This could indicate that in New York there is more segregation based on income than by occupations. For London the income based classification yields much lower levels of segregation than the pure occupations based classification. But again, the pattern over time is very similar for both classifications. This implied that in London there is more segregation based on occupations, so class-based, than on income. This is the opposite of what we found in New York. Finally, in Tokyo the income based classification yields marginally smaller levels of segregation than the pure occupations based classification, but the results are very similar. All in all, the patterns over time are very similar for all cities for both classifications. But for London the level of segregation is much lower when based on income compared to the occupational status classification.

\section{Supplementary Discussion}

\section{Discussion of background literature on occupational structure change in global cities}

Studies on socio-spatial change in global cities in the last 25 years have been strongly influenced by the research of Saskia Sassen ${ }^{1,2}$. The core of Sassen's argument was that the global dispersion of economic activities and the reorganization of financial services are the key processes that contribute to the concentration of central control and management functions of global companies and higherorder specialized firms. Typically, these firms congregate into global cities such as London, New York and Tokyo. According to Sassen ${ }^{1}$, "To understand the structure of a global city, we have to understand it as a place where certain kinds of work can get done (...). The 'things' a global city makes are highly specialized service and financial goods". Agglomeration economies emerge in global cities as a result of interactions between the higher order control and management functions of global companies on the one hand, and related higher-order services they need on the other hand. As these global companies grow, they tend to start outsourcing the more specialized higherorder services, thus creating new demand for a variety of such activities. This leads to a rapid increase in the number of companies providing high-skilled specialist services such as accountancy, advertisement, legal services and so on, and a high demand of people hired by these companies.

The consumption patterns of high-income earners further shape the occupational structure of the global city. These people create demand for low-skilled and low-wage labor, such as security guards and cleaning staff. According to Sassen", "The expansion of the high-income workforce, in conjunction with the emergence of new cultural forms of everyday living, has led to a process of high-income gentrification, which rests (...) on the availability of a vast supply of low-wage workers". The people taking up the low-skilled and low-wage jobs are often immigrants, particularly those from low-wage countries ${ }^{1,3}$. As a consequence, Sassen ${ }^{1}$ argued that “... the specific consequences of 
globalization have the effect not of contributing to the expansion of the middle class, as we saw in Fordism, but that the pressure is towards increasingly valuing top-level professional workers". The occupational structure may also get more polarized and dualized as the middle group thins out as a result of growing numbers of high-income earners who contribute to the growth of low-income earners through their consumption patterns. Strong evidence for such occupational polarization has been found in Toronto 4 .

Globalization not only affects occupational structures, but it also brings along increased income inequality between socio-economic groups ${ }^{1,5}$. In the globalized economy, the top socio-economic groups are able to benefit from a rising demand for their skills, which drives up their incomes, while the incomes of the bottom socio-economic groups are under pressure due to competition from lowincome countries ${ }^{6}$. As a consequence of this competition, some jobs have left high-income countries, while other jobs which remained have attracted immigrant labor ${ }^{7,8}$. But these processes are not uniform or global. For example, the level of international immigration into Tokyo is much lower than compared to London or New York ${ }^{1}$. The population growth of Tokyo since WWII was initially driven by internal migration from the rest of Japan, and latterly by natural growth, although growth has recently slowed down ${ }^{9}$. Likewise, the reduction in employment in manufacturing has been smaller in Tokyo compared to London and New York. Timberlake et al. ${ }^{10}$ have investigated the relationship between the global position of US cities and polarization in income and occupation. They show that inequalities in income mainly grow when there are high levels of international immigration, emphasizing the role of immigrants in occupational and income polarization.

The polarization thesis by Sassen ${ }^{1,2}$ has been extensively criticized. Hamnett ${ }^{7}$ found that while there was an increase in income inequalities in London during the 1980s, there was no evidence of polarization in the occupational structure, rather a trend towards professionalization. Furthermore, Hamnett has argued that occupational polarization in the US can also result from the weakness of the welfare state. Hill and Kim ${ }^{11}$ similarly argued that the role of the state is important by emphasizing the differences between Anglo-American liberalism and East Asian developmentalism, when comparing New York with Tokyo and Seoul. They argued that in contrast to market-centered and highly unequal countries such as US, the occupational structure in state-centered politicalbureaucratic countries tends to be more compressed around the middle, and the distribution to the two extremes is small. Tai ${ }^{12,13}$ also found significant differences in occupational change in developmental states in Asia. In the cities of Singapore, Hong Kong, Taipei and Seoul there was a trend towards professionalization, but without a growth in managers and self-employment. Tai ${ }^{12}$ found different patterns of social polarization in the 'city states' of Singapore and Hong Kong, and the 'capital cities' of Taipei and Seoul. Singapore and Hong Kong are examples of a centralized development model which uses immigrant labor. While Taipei and Seoul display anti-centralizing 
tendencies, combining measures to prevent brain-drain with immigration control for low-skilled foreign workers.

In short, there is evidence of different trajectories of occupational change in different cities, in different parts of the world. With regard to the three cities studied in this paper, deindustrialization has been less intense in Tokyo compared to London and New York, with little evidence of occupational and income polarization in Tokyo ${ }^{14,15}$. Rather, the main trend in Tokyo seems to have been professionalization. In London, similar to Tokyo, the main trend since the 1960s has been professionalization of the workforce, characterized by the expansion of managerial and professional jobs and the middle classes, at the expense of lower occupational groups ${ }^{7,16,17}$. However, Davidson and Wyly ${ }^{18}$ and Johnston and Manley ${ }^{19}$ found that the trend towards professionalization in London has ceased between 2001 and 2011. Johnston and Manley ${ }^{19}$ found no evidence that the top occupational groups (professionals and managers) and service class (a wide range of occupations involved in the service industry, including intermediates and lower supervisors) are crowding out the working class. In London, the working class has remained stable after the 2000s, however their share in absolute terms has contracted in the light of the overall population growth of London ${ }^{20,21}$ and there seems to be a growing diversity within the low-skilled occupational groups taking place 22 .

\section{Discussion of the changing social geography of global cities}

Fundamentally, the most critical cause of residential segregation between occupational groups is income inequality ${ }^{23-27}$. There is relatively little comparative research on the spatial footprint of occupational structure change in global cities ${ }^{28,29}$, but single-country studies on occupational and income segregation do exist ${ }^{26,30,31}$. The segregation profile by occupation and income is usually $\mathrm{U}$ shaped, with higher and lower occupational and income groups being more segregated than middle groups $^{32-34}$. Higher status occupational groups generally have higher incomes, and therefore have greater purchasing power in the urban housing market, where they can buy homes in the most desirable neighborhoods ${ }^{4,35}$.

However, the existence of income differences between groups is not sufficient to explain segregation, there should also be: (a) variation in the spatial opportunity structures in cities; an uneven geography of housing and other urban amenities; and (b) preferences towards living near people with a similar income, and preferences for certain neighborhoods, housing characteristics and urban amenities $26,27,36$. The uneven spatial distribution of housing types (by tenure, price, etcetera) directs people in different income groups into different neighborhoods. Generally, higher income households drive socio-economic segregation through their ability to move to the most attractive neighborhoods ${ }^{26}$. They tend to reveal their social class and status through the neighborhood in which they live ${ }^{37}$. In a strongly market-based housing system - in most countries 
the housing system becomes increasingly market based ${ }^{38,39}$ - income largely defines socio-spatial residential sorting mechanisms. With increasing income inequalities and commodification of housing, income-based sorting intensifies. As a result the residential choice set for lower income households reduces, and they become entrapped in a limited number of the least desirable neighborhoods ${ }^{40-42}$. As a result, both social and spatial mobility stagnates, as evidenced by persistently high levels of residential segregation and intergenerational reproduction of neighborhood choice ${ }^{43,44}$.

In cities in the US and Europe, but also elsewhere in the world, higher income groups tend to be more segregated than lower-income groups ${ }^{26,29}$. Growing incomes at the top, and/or a growth in the share of higher income earners in a city, drives property prices upwards in the most desirable neighborhoods, and fuels processes of gentrification in attractive central neighborhoods ${ }^{45,46}$. The distribution of income is more spread out across the top 20 percent of earners and more compressed for the equivalent bottom 20 percent at the low end of the distribution ${ }^{26}$. At the extreme of the top there is also the super-rich, and their residential choices and investments can lead to what Atkinson ${ }^{47}$ calls necrotecture or dead urban spaces. In global cities like London, New York and Tokyo, the most luxurious residential developments in central and waterfront areas, attract the wealthiest households, often with a foreign background, but many of these properties are not lived in, and are only bought as an investment, or for temporary stays $s^{47,48}$.

There has been a substantial increase in socio-economic segregation in the US since the Global Cities thesis was put forward by Sassen in $1991^{26,49,50}$. Likewise, socio-economic segregation has also grown in European capital cities, although levels are still lower than in the US ${ }^{29}$. In European cities it is not always the highest income households who are the most segregated. For example, in London lower occupational and income groups are more segregated than the higher occupational and income groups ${ }^{51}$. Possible explanations are related to two global spatial trends in terms of the residential choice of households: affluent households moving to gentrifying central neighborhoods, and the suburbanization of poverty ${ }^{52}$. In the initial stage of gentrification, high-income households move to previously low-income areas, which causes temporary mixing of income groups, also referred to as the "segregation paradox" 29,53 . As the process of gentrification proceeds, high-income earners push low-income households to the urban periphery. In many European cities, modernist low-cost and high rise housing estates at the edge of cities contributes to the spatial clustering of the poor, often people with an immigration background ${ }^{54}$. Like-wise, high-income earners may spill over from the most attractive central neighborhoods, to neighborhoods adjacent to them, causing temporary social mixing in these places. As a result, different types of change can be observed in residential segregation. The most desirable residential areas become unaffordable for lower income groups, spillover effects operate in adjacent areas, while lower-income groups are pushed towards the urban periphery. 
Less evidence has been found showing growing levels of segregation in Japan ${ }^{55,56}$. However, this might, at least in part, be due to the different nature of the segregation processes in densely built cities that are more common in Asia compared to Europe and the US. In high-density cities, vertical segregation is often more prominent than segregation between neighborhoods, with home values increasing from the bottom to the top of buildings ${ }^{57}$. At higher levels, there is less noise, a better view, and more daylight than at lower levels. In Europe a similar pattern of vertical segregation can be found in Athens ${ }^{58,59}$. To our knowledge, there has been no systematic research on vertical segregation by social class, income or occupation in US cities.

To conclude, processes of globalization and occupational restructuring (either polarization or professionalization) have different social and spatial implications for different global cities. The way in which changes in social structures affect the residential distribution of different occupational and income groups, is shaped by different mechanisms operating differently in different cities. Levels of segregation hinge on urban densities, morphologies and historical profiles of neighborhoods, and on political and institutional environments that shape, among others, the level on income inequality, level of immigration in a city, and the residential preferences of higher-income groups $26,27,60-62$. Moreover, externalities such as the economic cycle impact socio-spatial residential patterns. Tokyo is different from New York and London, because while Japan has experienced a very long economic slump after an asset-inflated bubble economy in the 1980s which burst in 1991, the US and European economies experienced a steady growth period, except for the recession period in the early 1990s, until the financial crisis hit in the late 2000s. We therefore expect that the growth in socio-economic segregation since the 1980s is the greatest in New York and the smallest in Tokyo, leaving London in-between. 


\section{Supplementary Figures}

Supplementary Figure 1. Occupational classification based on occupations and incomes as used in Figure 1 in the main paper

New York

1980

\begin{tabular}{|c|c|c|c|}
\hline Occupational classificatoin (1980 Census) & $\%$ & Income $^{a}$ & Group \\
\hline
\end{tabular} \begin{tabular}{|l|l|l|l|}
\hline Executive, administrative, and managerial occupations & 11,5 & 456 & High \\
\hline
\end{tabular} Professional specialty occupations Precision production, craft, and repair occupations Technicians and related support occupations

Protective service occupations

Transportation and material moving occupations

Sales occupations

Machine operators, assemblers, and inspectors Handers, equ Service occupations, except protective and househ Private household occupation

${ }^{a}$ Median weekly earnlngs (\$) (United States 1983)

Source: Current Population Survey (In Mellor 1985)

1990

\begin{tabular}{|l|c|c|c|}
\hline Occupational classificatoin (1990 Census) & $\%$ & Income $^{b}$ & Group \\
\hline
\end{tabular} \begin{tabular}{|l|c|c|c|c|}
\hline Executive, administrative, and managerial occupations & 13,5 & 728 & High \\
\hline
\end{tabular} Professional specialty occupations Technicians and related support occupations Precision production, craft, and repair occupations Transportation and material moving occupation Machine operators, assemblers, and inspectors

Handlers, equipment cleaners, helpers, and laborers \begin{tabular}{|l|c|c|c|}
\hline Administrative support occupations, including clerical & 20,7 & 390 & Middle \\
\hline
\end{tabular} Sales occupations

Private household occupations

352 Middle

Protective service occupation 245 Low

\begin{tabular}{|ll|l|l|}
\hline Service occupations, except protective and household & 12,5 & (Service) & Mow \\
& & Low
\end{tabular}

${ }^{\mathrm{b}}$ Median weekly earnlngs (\$) (United States 1989)

Source: Current Population Survey (In Ilg and Haugen 2000)

\section{London}

1981

\begin{tabular}{|c|c|c|c|}
\hline Socio-economic group (1981 Census) & $\%$ & Income & Group \\
\hline Employers and managers & 13,6 & 6.796 & High \\
\hline Professional workers & 4,8 & 6.658 & High \\
\hline Ancillary workers and artists & 10,9 & 5.637 & Middle \\
\hline Foremen and supervisors (non-manual) & 1,3 & 5.526 & Middle \\
\hline Foremen and supervisors (manual) & 2,0 & \multirow{3}{*}{$\begin{array}{c}5,197 \\
\text { (Skilled } \\
\text { manual) }\end{array}$} & Middle \\
\hline Skilled manual workers & 13,4 & & Middle \\
\hline Own account workers (other than professio & 4,6 & & Middle \\
\hline Semi-skilled manual workers & 10,4 & \multirow{2}{*}{$\begin{array}{l}4,520 \\
\text { (Semi- } \\
\text { skilled }\end{array}$} & Middle \\
\hline Personal service workers & 5,9 & & Low \\
\hline Junior non-manual workers & 27,5 & 4.229 & Low \\
\hline manual work & 5,5 & 4.035 & Low \\
\hline
\end{tabular}

Unskilled manual workers

EIncome: Male average annual pay (f) (Great Britain 1979)

Source: New Earnings Survey (In Routh 1980)

1991

\begin{tabular}{|l|c|c|c|}
\hline Occupational classificatoin (1991 Census & \% & Income $^{\mathrm{f}}$ & Group \\
\hline Managers and administrators & 19,2 & 385 & High \\
\hline Professional occupations & 11,2 & 355 & High \\
\hline Associate professional and technical occupa & 12,8 & 304 & Middle \\
\hline Craft and related occupations & 11,8 & 242 & Middle \\
\hline Plant and machine operatives & 6,9 & 220 & Middle \\
\hline Sales occupations & 6,5 & 213 & Low \\
\hline Personal and protective services occupation & 9,5 & 210 & Low \\
\hline Clerical and secretarial occupations & 22,0 & 191 & Low \\
\hline
\end{tabular}

reat Britain 1990

Source: New Earnings Survey
Tokyo

1980

\begin{tabular}{|l|c|l|l|}
\hline Occupational classificatoin $(\mathbf{1 9 8 0}$ Census & $\%$ & Income $^{\mathrm{i}}$ & Group \\
\hline
\end{tabular}

\begin{tabular}{|l|c|c|c|c|}
\hline Administrative and managerial workers & 7,3 & 25,7 & High \\
\hline
\end{tabular}

\begin{tabular}{|l|c|c|c|}
\hline Professional and technical workers & 10,9 & 14,1 & High \\
\hline
\end{tabular}

\begin{tabular}{|l|l|l|l|}
\hline Security workers & 1,1 & 12,1 & Middle \\
\hline
\end{tabular}

\begin{tabular}{|l|c|c|c|}
\hline Sales workers & 18,1 & 11,6 & Middle \\
\hline
\end{tabular}

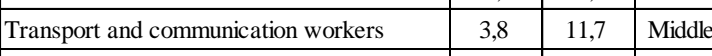

\begin{tabular}{|l|c|c|l|}
\hline Clerical workers & 22,7 & 10,7 & Middle \\
\hline
\end{tabular}

\begin{tabular}{|l|c|c|c|}
\hline Production process and related workers & 25,8 & 9,5 & Low \\
\hline Serce
\end{tabular}

Production

\begin{tabular}{|l|l|l|}
\hline 10,3 & 7,5 & Low \\
\hline
\end{tabular}

${ }^{i}$ Income: Mean daily wage (thousand Yen) (Tokyo Prefecture 1982)

Source: Employment Status Survey

1990

\begin{tabular}{|c|c|c|c|}
\hline )ccupational classificatoin (19) & $\%$ & Income $^{\mathrm{j}}$ & Group \\
\hline Administrative and managerial workers & 6,1 & 43,4 & High \\
\hline Professional and technical workers & 13,9 & 22,0 & High \\
\hline Sales workers & 18,0 & 19,5 & Middle \\
\hline Security workers & 1,1 & 19,5 & Middle \\
\hline Clerical workers & 24,7 & 18,2 & Middle \\
\hline Transport and communication workers & 3,4 & 17,7 & Middle \\
\hline Production process and related workers & 23,0 & 15,2 & Low \\
\hline Service workers & 9,7 & 12,0 & Low \\
\hline
\end{tabular}

j Income: Mean daily wage (thousand Yen) (Tokyo Prefecture 1992)

Source: Employment Status Survey 


\section{(Continued)}

2000

\begin{tabular}{|c|c|c|c|}
\hline Occupational classificatoin (2000 Census) & $\%$ & Income $^{c}$ & Group \\
\hline
\end{tabular} \begin{tabular}{|l|l|l|l|}
\hline Management, business, and financial operations occul & 13,5 & 35,3 & High \\
\hline
\end{tabular}

Professional and related occupations

\begin{tabular}{|l|c|c|c|}
\hline Construction, extraction, and maintenance occupation & 6,4 & 19,5 & Middle \\
\hline
\end{tabular}

\begin{tabular}{|l|l|l|l|l|}
\hline Protective service occupations & 2,9 & 17,4 & Middle \\
\hline
\end{tabular}

Sales and related occupations

Office and administrative support occupations

Transportation and material moving occupations

Production occupations

\begin{tabular}{|l|l|l|l|l|}
\hline Building and grounds cleaning and maintenance occur & 3,8 & 11,8 & Low \\
\hline
\end{tabular}

Healthcare support occupations

Personal care and service occupations

Food preparation and serving related occupations

${ }^{\mathrm{c}}$ Mean hourly wage (\$) (New York State 2000)

Source: Occupational Employment Statistics

\section{0}

\begin{tabular}{|l|c|l|l|}
\hline Occupational classificatoin (2010 Census) & $\%$ & Income $^{\mathrm{d}}$ & Group \\
\hline
\end{tabular}

\begin{tabular}{|l|l|c|c|c|}
\hline Management, business, and financial operations occul & 14,2 & 50,6 & High \\
\hline
\end{tabular}

Professional and related occupations

\begin{tabular}{|l|l|l|l|}
\hline Construction, extraction, and maintenance occupation & 63,4 & 33,8 & High \\
\hline
\end{tabular}

\begin{tabular}{|l|c|c|c|}
\hline Protective service occupations & 3,0 & 23,0 & Middle \\
\hline
\end{tabular}

Sales and related occupations

Office and administrative support occupations

Transportation and material moving occupations

Production occupations

Building and grounds cleaning and maintenance occ

Healthcare support occupations

Personal care and service occupations

Food preparation and serving related occupations

${ }^{\mathrm{d}}$ Mean hourly wage (\$) (New York State 2010)

Source: Occupational Employment Statistics

\begin{tabular}{|l|l|l|}
\hline 4,0 & 10,9 & Low \\
\hline 3,4 & 10,2 & Low \\
\hline
\end{tabular}

\begin{tabular}{|l|l|l|}
\hline 4,5 & 8,4 & Low \\
\hline
\end{tabular}

2001

\begin{tabular}{|l|c|l|l|}
\hline Occupational classificatoin (2001 Census & $\%$ & Income $^{2}$ & Group \\
\hline M & 17,6 & 601 & Heg \\
\hline
\end{tabular} Managers and senior officials

Professional occupations

Associate professional and technical occup

Skilled trades occupations

Process, plant and machine operatives

Administrative and secretarial occupation

Personal service occupations

Elementary occupations

Sales and customer service occupations

${ }^{\mathrm{g}}$ Income: Median weekly pay (£) (London 2000)

Source: Annual Survey of Hours and Earnings

\begin{tabular}{|c|c|c|}
17,6 & 601 & High \\
\hline
\end{tabular}

\begin{tabular}{|c|c|c|}
\hline 14,9 & 560 & High \\
\hline
\end{tabular}

\begin{tabular}{|c|c|c|}
\hline 17,9 & 489 & Middle \\
\hline
\end{tabular}

\begin{tabular}{|c|c|c|}
\hline 7,7 & 416 & Middle \\
\hline
\end{tabular}

\begin{tabular}{|c|c|c|}
\hline 4,9 & 350 & Middle \\
\hline
\end{tabular}

\begin{tabular}{|c|c|c|}
\hline 15,5 & 303 & Middle \\
\hline
\end{tabular}

\begin{tabular}{|c|c|c|}
\hline 5,9 & 259 & Low \\
\hline 8,9 & 186 & Low \\
\hline
\end{tabular}

\begin{tabular}{|c|c|c|}
\hline 8,9 & 186 & Low \\
\hline 6,7 & 146 & Low \\
\hline
\end{tabular}

2011

\begin{tabular}{|l|c|c|c|}
\hline \multicolumn{1}{|c|}{$\mathbf{1}$} & $\mathbf{\%}$ & Income $^{\mathrm{f}}$ & Group \\
\hline Managers and senior officials & 11,6 & 950 & High \\
\hline Professional occupations & 22,4 & 809 & High \\
\hline Associate professional and technical occupa & 16,3 & 662 & Middle \\
\hline Process, plant and machine operatives & 4,7 & 525 & Middle \\
\hline Skilled trades occupations & 8,3 & 522 & Middle \\
\hline Administrative and secretarial occupations & 11,7 & 487 & Middle \\
\hline Personal service occupations & 7,8 & 402 & Low \\
\hline Elementary occupations & 9,6 & 364 & Low \\
\hline Sales and customer service occupations & 7,5 & 342 & Low \\
\hline
\end{tabular}

${ }^{\mathrm{g}}$ Income: Median weekly pay (£) (London 2010)

Source: Annual Survey of Hours and Earnings
2000

\begin{tabular}{|c|c|c|c|}
\hline Occupational classificatoin (2000 Census & $\%$ & Income $^{\mathrm{k}}$ & Group \\
\hline
\end{tabular}

\begin{tabular}{|l|c|c|c|}
\hline Administrative and managerial workers & 4,4 & 38,7 & High \\
\hline
\end{tabular}

\begin{tabular}{|l|c|c|c|c|}
\hline Professional and technical workers & 16,3 & 22,5 & High \\
\hline
\end{tabular}

\begin{tabular}{|l|c|c|c|}
\hline Security workers & 1,3 & 20,6 & Middle \\
\hline Cle & 24,9 & 19,1 & Mide \\
\hline
\end{tabular}

\begin{tabular}{|l|c|c|c|}
\hline Clerical workers & 24,9 & 19,1 & Middle \\
\hline
\end{tabular}

\begin{tabular}{|l|c|c|l|}
\hline Sales workers & 18,6 & 18,7 & Middle \\
\hline Trang and
\end{tabular}

\begin{tabular}{|l|c|c|c|}
\hline Transport and communication workers & 3,4 & 16,7 & Middle \\
\hline
\end{tabular}

\begin{tabular}{|l|c|c|c|}
\hline Production process and related workers & 20,1 & 14,4 & Low \\
\hline
\end{tabular}

Service workers

\begin{tabular}{l|l|l|}
11,0 & 10,1 & Low \\
\hline
\end{tabular}

${ }^{\mathrm{k}}$ Income: Mean daily wage (thousand Yen) (Tokyo Prefecture 2002)

Source: Employment Status Survey
2010

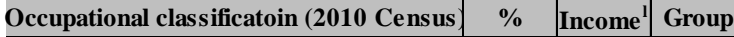

\begin{tabular}{|l|c|c|c|c|}
\hline Administrative and managerial workers & 3,9 & 38,0 & High \\
\hline
\end{tabular}

\begin{tabular}{|l|c|c|c|}
\hline Professional and engineering workers & 19,8 & 22,3 & High \\
\hline Cle
\end{tabular}

\begin{tabular}{|l|c|c|c|}
\hline Clerical workers & 26,2 & 20,0 & Middle \\
\hline
\end{tabular}

\begin{tabular}{|l|c|c|l|}
\hline Security workers & 1,5 & 18,9 & Middle \\
\hline
\end{tabular}

\begin{tabular}{|l|c|c|l|}
\hline Sales workers & $1,5,6$ & 18,1 & Middle \\
\hline
\end{tabular}

\begin{tabular}{|l|l|l|l|}
\hline Construction and mining workers & 3,1 & 16,0 & Low \\
\hline
\end{tabular}

\begin{tabular}{|l|c|c|c|}
\hline Transport and machine operation workers & 3,0 & 15,0 & Middle \\
\hline
\end{tabular}

\begin{tabular}{|l|c|c|c|}
\hline Manufacturing process workers & 7,8 & 13,5 & Low \\
\hline
\end{tabular}

\begin{tabular}{|l|c|c|c|}
\hline Service workers & 12,4 & 9,2 & Low \\
\hline
\end{tabular}

\begin{tabular}{|lc|c|c|}
\hline Carrying, cleaning, packaging, and related wo & 12,4 & 9,2 & Low \\
\hline
\end{tabular}

Income: Mean daily wage (thousand Yen) (Tokyo Prefecture 2012)

Source: Employment Status Survey 


\section{Supplementary Figure 2. Maps with the authority names of three global cities}

\section{New York}

Bronx

1.Throggs Neck, 2.Morris Park, 3.Baychester, 4.Fordham, 5.Spuyten Duyvil, 6.Mott Haven, 7.Williams Bridge, 8.Union Port, 9.Soundview, 10.Morris Heights, 11.Country Club, 12.Kings Bridge, 13.University Heights, 14.City Island, 15.Bedford Park, 16.Wakefield-Williamsbridge, 17.Hunts Point, 18.High Bridge, 19.Riverdale, 20.Eastchester, 21. Woodlawn-Nordwood, 22.Tremont, 23.Parkchester, 24.South Bronx

\section{Manhattan}

1.West Village, 2.East Village, 3.Battery Park, 4.Carnegie Hill, 5.Gramercy, 6.Soho, 7.Murray Hill, 8.Little Italy, 9.Central Park, 10.Greenwic Village, 11.Midtown, 12.Morningside Heights, 13. Harlem, 14. Hamilton eights, 15.Tribeca, 18. North Sutton Area, 17.Upper East Side, 18.Financial District, 19.Inwood, 20.Chelsea, 21.Lower East Side, 22.Chinatown, 23.Washington Heights, 24.Upper West Side, 25.Clinton, 26.Yorkville, 27.Garment District, 28.East Harlem

Brooklyn

Bensonhurst, 2.Mapleton-Flattlands, 3.Bay Ridge, 4.Boerum Hill, 5.Cobble Hill, 6.Downtown, 7.Coney Island, 8.Sunset Park, 9.Borough Park, 10.East Brooklyn, 11.Bedford-Stuyvesant, 12.Flatbush, 13.Park Slope, 14.Williamsburg, 15.Canarsie, 16.Greenwood, 17.Gravesend-Sheepshead Bay, 18.Red Hook, 19.Carroll Gardens, 20.Dyker Heights, 21.Brownsville, 22.Bushwick, 23.Fort Green

Queens

.Auburndale, 2.College Point, 3.Douglastown-Little Neck, 4.Queens Village, 5.Middle Village, 6.Woodside, 7.Rosedale, 8.Nkew Gardens, 9.Whitestone, 10.Woodhaven-Richmond Hill, 11.Jamaica, 12.Laurelton, 13.Jackson Heights, 14.Maspeth, 15.Glendale, 16.Steinway, 17.Flushing, 18.Saintalbans, 19.Queensboro Hill, 20.Springfield Gardens, 21.Astoria-Long Island City, 22.Sunny Side, 23.Ridgewood, 24.Forest Hills, 25.The Rockaway5, 26.Clearview.

Staten Island

1.Rosebank, 2.Mariners Harbor, 3.Rossville, 4.Great Kills, 5.New Brighton, 6.Ettingville, 7.Port Richmond, 8.Woodrow, 9.Charlestown-Richmond Valley, 10.Huguenot,

11.Bloomfield-Chelsea-Travis, 12.Richmondtown, 13.Annandale, 14.Midland Beach, 15. Oakwood, 16. South Beach, 17. Tottensville, 18. Howland Hook, 19.Ardon Heights, 20.Prince's Bay, 21. Fresh Kills, 22. Clifiton, 23. Todt Hill, 24. Westerleigh-Castleton
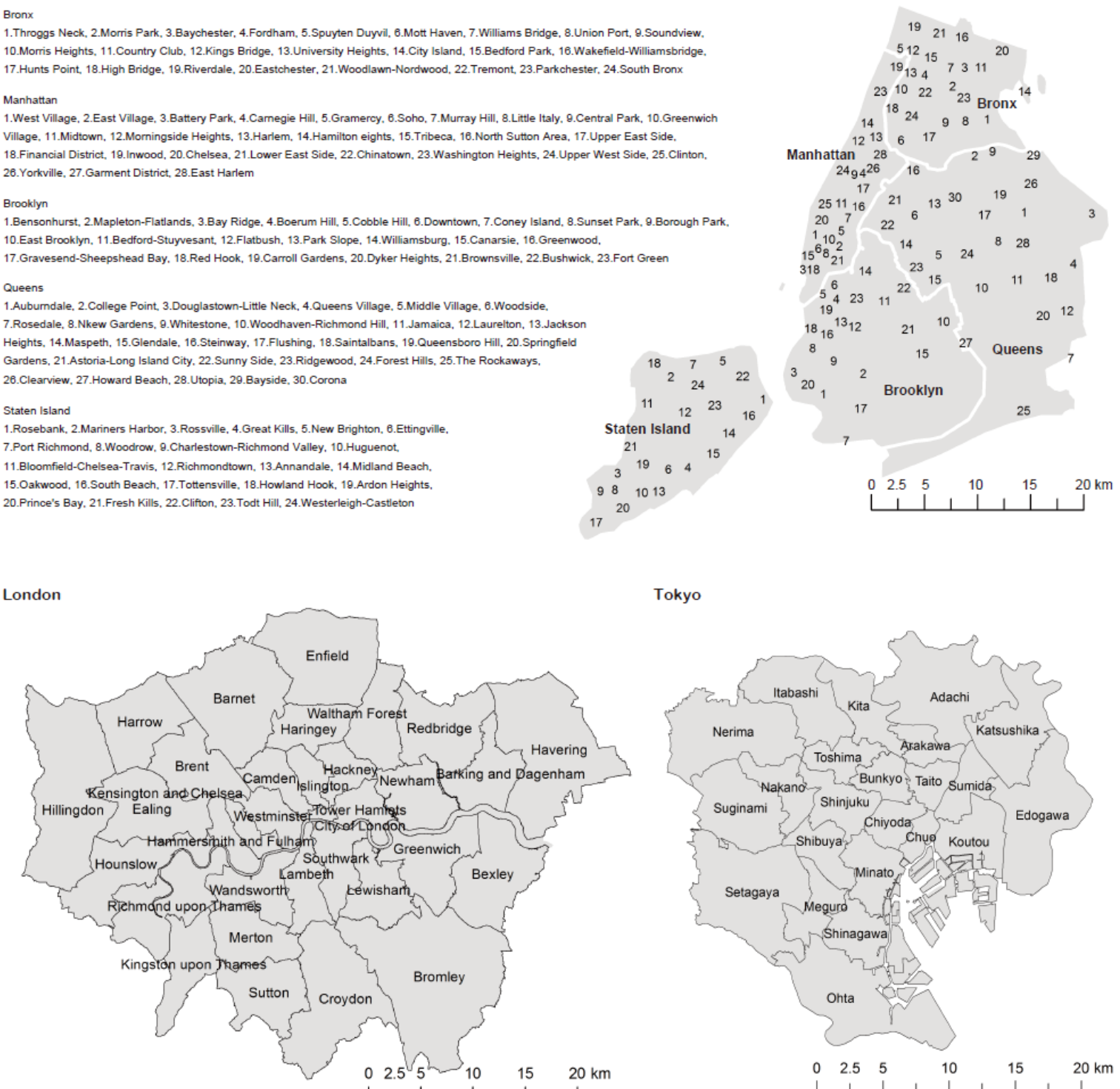

Tokyo

Maps were created using ArcGIS software by Esri. The New York shapefile originates from reference 63. The London map contains National Statistics data (C) Crown copyright and database right [2015] and contains Ordnance Survey data (C) Crown copyright and database right [2015]. 
Supplementary Figure 3. Occupational status groups based on occupations only, not including income; this figure was used as a robustness check for Figure 1 in the main paper

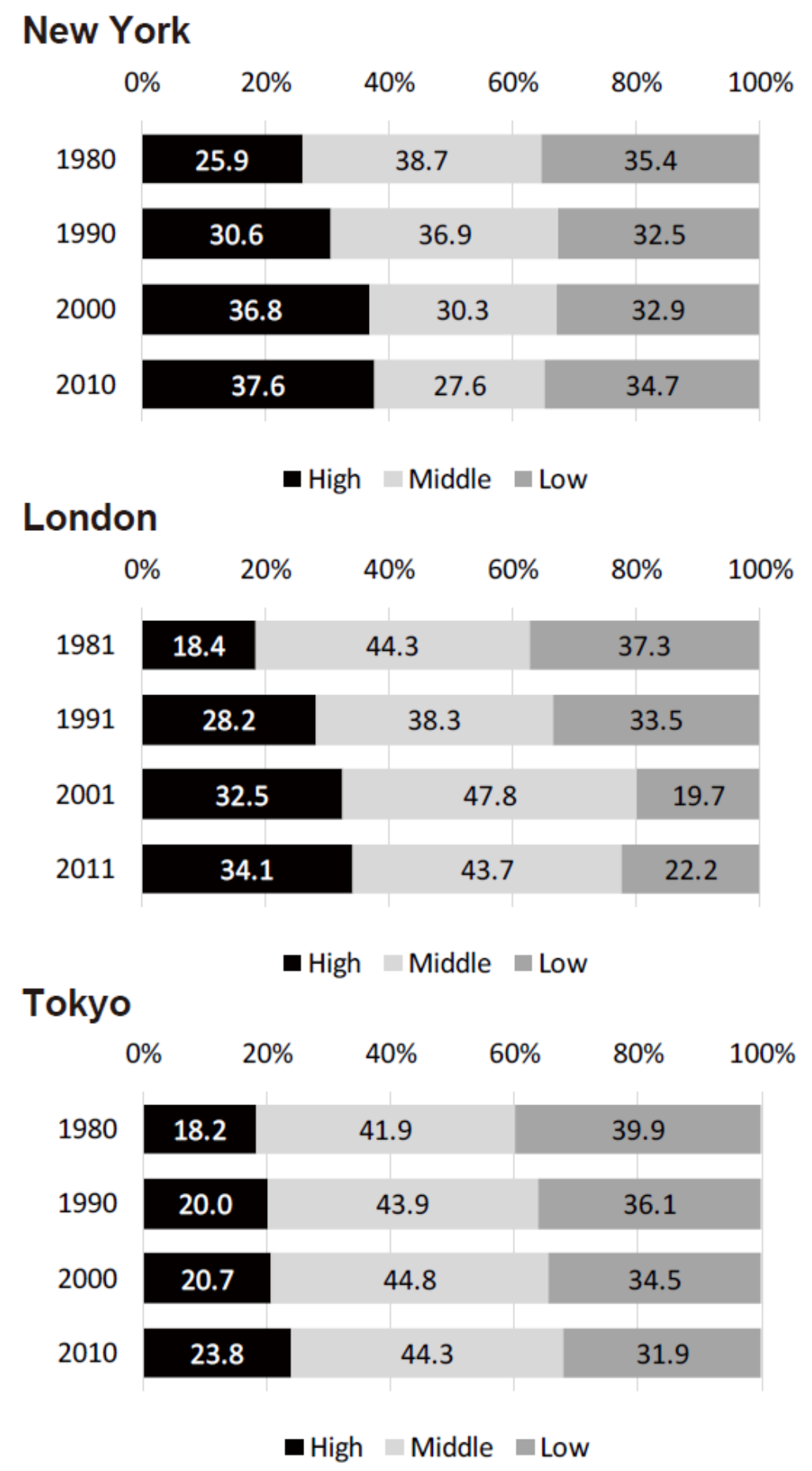




\section{Supplementary Tables}

Supplementary Table 1. Details of survey data used Occupational classification

\begin{tabular}{|c|c|c|c|c|c|c|c|c|}
\hline Year & Year & Survey & Earnings & Sample & Full / part time & Tax & Unit (Area) & $\begin{array}{l}\text { Detail of occupational } \\
\text { classification }\end{array}$ \\
\hline \multirow[t]{4}{*}{ New York } & 1983 & $\begin{array}{l}\text { Current Population Survey (Bureau of } \\
\text { Labor Statistics) }\end{array}$ & Median / Weekly & 60,000 households & Full time & Before tax & United States & Less detail than Census \\
\hline & 1989 & $\begin{array}{l}\text { Current Population Survey (Bureau of } \\
\text { Labor Statistics) }\end{array}$ & Median / Weekly & 60,000 households & Full time & Before tax & United States & Less detail than Census \\
\hline & 2000 & $\begin{array}{l}\text { Occupational Employment } \\
\text { (Bureau of Labor Statistics) }\end{array}$ & Mean / Hourly & 200,000 establishments & Full time & Before tax & New York State & Same as Census \\
\hline & 2010 & $\begin{array}{l}\text { Occupational Employment Statistics } \\
\text { (Bureau of Labor Statistics) }\end{array}$ & Mean / Hourly & 200,000 establishments & Full time & Before tax & New York State & Same as Census \\
\hline \multirow[t]{4}{*}{ London } & 1979 & $\begin{array}{l}\text { New Earnings Survey (Office for National } \\
\text { Statistics) }\end{array}$ & Average / Annual & $1 \%$ sample & Full time & Before tax & Great Britain & Less detail than Census \\
\hline & 1990 & $\begin{array}{l}\text { New Earnings Survey (Office for National } \\
\text { Statistics) }\end{array}$ & Median / Weekly & $1 \%$ sample & Full time & Before tax & Great Britain & More detail than Census \\
\hline & 2000 & $\begin{array}{l}\text { Annual Survey of Hours and Earnings } \\
\text { (Office for National Statistics) }\end{array}$ & Median / Weekly & 180,000 employees (1\%) & Full time & Before tax & London Region & Same as Census \\
\hline & 2010 & $\begin{array}{l}\text { Annual Survey of Hours and Earnings } \\
\text { (Office for National Statistics) }\end{array}$ & Median / Weekly & 180,000 employees (1\%) & Full time & Before tax & London Region & Same as Census \\
\hline \multirow[t]{4}{*}{ Tokyo } & 1982 & $\begin{array}{l}\text { Employment Status Survey (Statistics } \\
\text { Bureau) }\end{array}$ & Mean / Daily & 410,000 households & $\begin{array}{l}\text { Full time and } \\
\text { part time }\end{array}$ & Before tax & Tokyo Prefecture & Same as Census \\
\hline & 1992 & $\begin{array}{l}\text { Employment Status Survey (Statistics } \\
\text { Bureau) }\end{array}$ & Mean / Daily & 430,000 households & $\begin{array}{l}\text { Full time and } \\
\text { part time }\end{array}$ & Before tax & Tokyo Prefecture & Same as Census \\
\hline & 2002 & $\begin{array}{l}\text { Employment Status Survey (Statistics } \\
\text { Bureau) }\end{array}$ & Mean / Daily & 440,000 households & $\begin{array}{l}\text { Full time and } \\
\text { part time }\end{array}$ & Before tax & Tokyo Prefecture & Same as Census \\
\hline & 2012 & $\begin{array}{l}\text { Employment Status Survey (Statistics } \\
\text { Bureau) }\end{array}$ & Mean / Daily & 470,000 households & $\begin{array}{l}\text { Full time and } \\
\text { part time }\end{array}$ & Before tax & Tokyo Prefecture & Same as Census \\
\hline
\end{tabular}


Supplementary Table 2. Index of dissimilarity (ID) and Multi-group dissimilarity index (MDI) based on occupational status groups based on occupations only, not taking income into account.

\begin{tabular}{|c|c|c|c|c|c|c|c|c|}
\hline & \multicolumn{4}{|l|}{$I D^{a}$} & \multicolumn{4}{|l|}{$\mathrm{MDI}^{\mathrm{a}}$} \\
\hline & $\begin{array}{l}\text { New York } \\
\text { (CT) }\end{array}$ & $\begin{array}{l}\text { London } \\
\text { (LSOA) }\end{array}$ & $\begin{array}{l}\text { Tokyo } \\
\text { Grid }\end{array}$ & Cho & $\begin{array}{l}\text { New York } \\
\text { (CT) }\end{array}$ & $\begin{array}{l}\text { London } \\
\text { (LSOA) }\end{array}$ & $\begin{array}{l}\text { Tokyo } \\
\text { Grid }\end{array}$ & Cho \\
\hline 1980 & 0.4177 & $0.3832^{b}$ & 0.2750 & - & 0.2440 & $0.2188^{b}$ & 0.1525 & - \\
\hline 1990 & 0.3935 & $0.3270^{\mathrm{b}}$ & 0.2670 & - & 0.2353 & $0.1925^{b}$ & 0.1436 & - \\
\hline 2000 & 0.3887 & 0.3174 & 0.2420 & 0.2480 & 0.2492 & 0.1638 & 0.1293 & 0.1340 \\
\hline 2010 & 0.4127 & 0.3221 & - & 0.2450 & 0.2753 & 0.1658 & - & 0.1290 \\
\hline
\end{tabular}

a ID: Top and Bottom, MDI: 3 group (Top, Middle and Bottom). 


\section{Supplementary References}

1 Sassen, S. The global city: New York, London, Tokyo 2nd edition. (Princeton University Press, 2001).

2 Sassen, S. The global city. (Wiley, 1991).

3 Friedmann, J. The world city hypothesis. Development and Change 17, 69-84 (1986).

$4 \quad$ Hulchanski, J. D. The Three Cities Within Toronto: Income Polarization Among Toronto's Neighbourhoods, 1970-2005. (University of Toronto, 2010).

$5 \quad$ Piketty, T. Capital in the 21st Century. (Harvard University Press, 2013).

6 Heckscher, E. F. \& Ohlin, B. Factor Endowment and Factor proportion Theory. 193-197 (Harvard University Press, 1933).

7 Hamnett, C. Social polarisation, economic restructuring and welfare state regimes. Urban Studies 33, 1407-1430 (1996).

8 Hamnett, C. Social polarisation in global cities: theory and evidence. Urban studies 31, 401424 (1994).

9 TMG. Tokyo Metropolitan Government; Tokyo's history, geography and population. (2019).

10 Timberlake, M. et al. Testing a global city hypothesis: An assessment of polarization across US cities. City \& Community 11, 74-93 (2012).

11 Hill, R. C. \& Kim, J. W. Global Cities and Developmental States: New York, Tokyo and Seoul. Urban Studies 37, 2167-2195 (2000).

12 Tai, P. F. Beyond 'social polarization'? A test for Asian world cities in developmental states. International Journal of Urban and Regional Research 34, 743-761 (2010).

13 Tai, P. F. Social Polarisation: Comparing Singapore, Hong Kong and Taipei. Urban Studies 43, 1737-1756 (2006).

14 Machimura, T. Sekai toshi Tokyo no kouzou tenkan [The structural change of a global city: urban restructuring in Tokyo]. (University of Tokyo Press, 1994).

15 Sonobe, M. Gendai daitoshi shakai ron: bunkyokukasuru toshi? [Contemporary metropolitan society: dual city?]. (Toshindo Publishing, 2001).

16 Butler, T., Hamnett, C. \& Ramsden, M. Inward and upward: marking out social class change in London, 1981-2001. Urban Studies 45, 67-88 (2008).

17 Hamnett, C. Socio-economic change in London: professionalization not polarization. Built Environment 20, 192-203 (1994).

18 Davidson, M. \& Wyly, E. Classifying London. City 16, 395-421 (2012).

19 Johnston, R. \& Manley, D. London: A dividing city, 2001-11? City 18 (2014).

20 Hamnett, C. \& Butler, T. Re-classifying London: a growing middle class and increasing inequality: a response to Mark Davidson and Elvin Wyly's 'Class-ifying London: Question Social Division and Space Claims in the Post-industrial Metropolis'. City 17, 197-208 (2013).

21 Hamnett, C. The changing occupational class composition of London. City 19, 239-246 (2015).

22 Davidson, M. \& Wyly, E. Same but different: Within London's 'static' class structure and the missing antagonism. clTY 19, 247-257 (2015).

23 Andersson, E. K., Lyngstad, T. H. \& Sleutjes, B. Comparing patterns of segregation in NorthWestern Europe: A multiscalar approach (editorial introduction to special issue). European Journal of Population 34, 151-168, doi:10.1007/s10680-018-9477-1 (2018).

24 Nightingale, C. H. A global history of divided cities. (University of Chicago Press, 2012).

25 Préteceille, E. in Residential segregation in comparative perspective: Making sense of contextual diversity (eds K Fujita \& T Maloutas) (Routledge, 2016).

26 Reardon, S. \& Bischoff, K. Income inequality and income segregation. American Journal of Sociology 116, 1092-1153 (2011).

27 Tammaru, T., van Ham, M., Janssen, H., Marcinczak, S. \& Aunap, R. Relationship between income inequality and residential segregation between socioeconomic groups. Regional Studies, 1-12 (2019). 
28 Musterd, S. Social and Ethnic Segregation in Europe: Levels, Causes, and Effects. Journal of Urban Affairs 27, 341-348 (2005).

29 Tammaru, T., Marcińczak, S., van Ham, M. \& Musterd, S. Socio-Economic Segregation in European Capital Cities: East Meets West. (2016).

30 Johnston, R., Forrest, J., Jones, K. \& Manley, D. The scale of segregation: ancestral groups in Sydney. Urban Geography 37, 985-1008 (2016).

31 Marcińczak, S. \& Sagan, I. The Socio-Spatial Restructuring of Lodz, Poland. Urban Studies 48, 1789-1809, doi:10.1177/0042098010379276 (2011).

32 Duncan, O. \& Duncan, B. Residential distribution and occupational stratification. American Journal of Sociology 60, 493-503 (1955).

33 Morgan, B. The segregation of socio-economic groups in urban areas: A comparative analysis. Urban Studies 12, 47-60 (1975).

34 Manley, D., Johnston, R., Jones, K. \& Owen, D. in Socio-Economic Segregation in European Capital Cities: East Meets West (eds T Tammaru, S Marcińczak, M van Ham, \& S Musterd) (Routledge, 2016).

35 Musterd, S., Marcińczak, S., van Ham, M. \& Tammaru, T. Socioeconomic segregation in European capital cities. Increasing separation between poor and rich. Urban Geography 38, 1062-1083 (2017).

36 Tiebout, C. M. A pure theory of local expenditures. Journal of political economy 64, 416-424 (1956).

37 Hedman, L., van Ham, M. \& Manley, D. Neighbourhood choice and neighbourhood reproduction. Environment and Planning A 43, 1381-1399 (2011).

38 Aalbers, M. B. The Financialization of Housing: A political economy approach. (Routledge, 2016).

39 Rolnik, R. Late Neoliberalism: The Financialization of Homeownership and Housing Rights. International Journal of Urban and Regional Research 37, 1058-1066 (2013).

40 Leal, J. \& Sorando, D. in Socioeconomic segregation in European Capital Cities: East Meets West (eds T Tammaru, S Marcinczak, M van Ham, \& S Musterd) 214-237 (Routledge, 2016).

41 Malpass, P. Reshaping housing policy : subsidies, rents and residualisation. (Routledge, 1990).

42 Nieuwenhuis, J., Tammaru, T., Van Ham, M., Hedman, L. \& Manley, D. Does segregation reduce socio-spatial mobility? Evidence from four European countries with different inequality and segregation contexts. Urban Studies, 1-22 (2019).

43 Krysan, M. \& Crowder, K. Cycle of segregation. Social processes and residential stratification. (Russell Sage Foundation, 2017).

44 van Ham, M., Tammaru, T. \& Janssen, H. J. in Divided cities: understanding intra-urban disparities (OECD, 2018).

45 Atkinson, R. Limited exposure: Social concealment, mobility and engagement with public space by the super-rich in London. Environment and Planning A: Economy and Space 48, 13021307 (2016).

46 Hamnett, C. Spatially displaced demand and the changing geography of house prices in London, 1995-2006. Housing Studies 24, 301-320 (2009).

47 Atkinson, R. \& Ho, H.-K. in Research Handbook on Urban Segregation (ed S Musterd) (Edward Elgar, 2019).

48 Forrest, R., Koh, S. Y. \& Wissink, B. Cities and the super-rich: Real estate, elite practices and urban political economies. (Springer, 2017).

49 Fischer, C. S., Stockmayer, G., Stiles, J. \& Hout, M. Distinguishing the Geographic Levels and Social Dimensions of U.S. Metropolitan Segregation, 1960-2000. Demography 41, 37-59 (2004).

50 Watson, T. Inequality and the Measurement of Residential Segregation by Income in American Neighborhoods. Review of Income and Wealth 55, 820-844 (2009). 
51 Manley, D., Johnston, R., Jones, K. \& Owen, D. Macro-, meso-and microscale segregation: Modeling changing ethnic residential patterns in Auckland, New Zealand, 2001-2013. Annals of the Association of American Geographers 105, 951-967 (2016).

52 Hochstenbach, C. \& Musterd, S. Gentrification and the suburbanization of poverty: Changing urban geographies through boom and bust periods. Urban Geography 39, 26-53 (2018).

53 Sýkora, L. \& Bouzarovski, S. Multiple transformations: conceptualising post-communist urban transition. Urban Studies 49, 41-58 (2012).

54 Hess, D. B., Tammaru, T. \& van Ham, M. in Housing estates in Europe: poverty, segregation, and policy challenges (eds D. B Hess, T Tammaru, \& M Van Ham) 1-3 (Springer, Dordrecht, 2018).

55 Fielding, A. J. Class and space: social segregation in Japanese cities. Transactions of the Institute of British Geographers 29, 64-84 (2004).

56 Fujita, K. \& Hill, R. C. in Residential segregation in comparative perspective: Making sense of contextual diversity (eds T Maloutas \& K Fujita) 54-86 (Ashgate, 2012).

57 Hirayama, Y. in Cities and the Super-rich: Real Estate, Elite Practices and Urban Political Economies (eds R Forrest, D Wissink, \& S.Y Koh) (Palgrave Macmillan, 2016).

58 Maloutas, T. in Socio-Economic Segregation in European Capital Cities. East meets West (eds T Tammaru, Szymon Marcińczak, M van Ham, \& S Musterd) 156-185 (Routledge, 2016).

59 Maloutas, T. \& Spyrellis, S. N. Vertical segregation: Mapping the vertical social stratification of residents in Athenian apartment buildings. La ségrégation dans les villes de l'Europe méditerranéenne, 27-36 (2016).

60 Maloutas, T. \& Fujita, K. Residential Segregation in Comparative Perspective. Making Sense of Contextual Diversity. (Ashgate, Farnham, 2012).

61 Marcińczak, S. et al. Patterns of socioeconomic segre-gation in the capital cities of fast-track reforming postsocialist countries. Annals of the Association of American Geographers 105, 183-202 (2015).

62 van Kempen, R. Divided cities in the 21st century: Challenging the importance of globalization. Journal of Housing and Built Environment 22, 13-31 (2007).

63 Zillow-neighborhoods@public neighborhood boundaries (2018). https://www.zillow.com/howto/api/neighborhood-boundaries.htm 